\title{
Nitrogen Balance for a Plantation Forest Drainage Canal on the North Carolina Coastal Plain
}

\author{
T. W. Appelboom, G. M. Chescheir，R. W. Skaggs，J. W. Gilliam，D. M. Amatya
}

\begin{abstract}
Human alteration of the nitrogen cycle has led to increased riverine nitrogen loads, contributing to the eutrophication of lakes, streams, estuaries, and near-coastal oceans. These riverine nitrogen loads are usually less than the total nitrogen inputs to the system, indicating nitrogen removal during transport through the drainage network. A two-year monitoring study quantified the ammonium, nitrate, and organic- $N$ inputs, outputs, and inferred in-stream processes responsible for nitrogen transformations and removal in a $1900 \mathrm{~m}$ reach of a drainage canal located in a managed pine plantation. Total nitrogen inputs to the canal section were $527.8 \mathrm{~kg}$ in 2001 and $1422.7 \mathrm{~kg}$ in 2002. Total nitrogen discharge at the outlet was $502 \mathrm{~kg}$ in 2001 and $1458 \mathrm{~kg}$ in 2002. The mass balance of nitrogen inputs and outputs indicated a loss of $25.8 \mathrm{~kg}(5.1 \%)$ of total nitrogen from the system in 2001, and a gain of $35.3 \mathrm{~kg}(2.4 \%)$ of total nitrogen to the system in 2002. Variability in the input and output estimates was high, especially for groundwater exchange. Different hydrologic and nitrogen inputs and outputs were identified and quantified, but measurement variability obscured any potential nitrogen removal from the system.
\end{abstract}

Keywords. In-stream processes, Nitrogen budget, Nitrogen mass balance, Nitrogen transformations, Water quality.

A s populations increase, human activities related to food, timber, clothing, and energy production focus on managing biological systems to increase yields. Many of these activities have adversely affected the environment, impacting natural element cycles (carbon, sulfur, nitrogen, and phosphorous) on every continent (Erisman et al., 1998; EEA, 1995). Increased nitrogen and phosphorous transport to coastal and aquatic environments, e.g., the Gulf of Mexico (Rabalais et al., 2002), North Sea (North Sea Task Force, 1993), Baltic Sea (EEA, 1995), Black Sea (Mee, 1992), and Chesapeake Bay (Officer et al., 1984), have been linked to increased riverine nutrient loads. These nutrient increases have multiple sources, including agriculture, forestry, municipalities, and atmospheric deposition (Poor et al., 2001). In forested watersheds, fertilization (Binkley et al., 1999), increased mineralization/nitrification and leaching from forest soils during wet-dry sequences (Lamersdorf et al., 1998), and increased atmospheric nitro-

Submitted for review in November 2006 as manuscript number SW 6734; approved for publication by the Soil \& Water Division of ASABE in June 2008. Presented at the 2005 ASABE Annual Meeting as Paper No. 052196 .

The authors are Timothy W. Appelboom, ASABE Member Engineer, Research Associate Agricultural Engineer, USDA Agricultural Research Service, Baton Rouge, Louisiana; George M. Chescheir, ASABE Member Engineer, Research Assistant Professor, Department of Biological and Agricultural Engineering, R. Wayne Skaggs, ASABE Fellow, William Neal Reynolds and Distinguished University Professor, Department of Biological and Agricultural Engineering, and J. Wendel Gilliam, Retired Professor, Department of Soil Science, North Carolina State University, Raleigh, North Carolina; and Devendra M. Amatya, ASABE Member Engineer, Research Hydrologist, USDA Forest Service, Charleston, South Carolina. Corresponding author: Timothy W. Appelboom, USDA Agricultural Research Service, 4115 Gourrier Ave., Baton Rouge, LA 70808-4499; phone: 225-578-0745; fax: 225-757-7728; e-mail: tappelboom@msa-stoneville.ars.usda.gov. gen deposition (Seely et al., 1998) have led to increased nitrogen loads in drainage water.

Total nitrogen inputs to drainage ditches and canals usually exceed loads discharged at the outlet (e.g., Triska et al., 1984; Meyer et al., 1981). This indicates nitrogen removal from, or retention within, the system via in-stream processes. In-stream processes transform elements by physically, chemically, and/or biologically changing their physical or chemical state (Meyer et al., 1981; Cummins, 1974; Boling et al., 1981). The impacts of in-stream processes on nitrogen delivered to sensitive receiving waters have critical management implications for a watershed. If limited resources are available to reduce nitrogen loads but some nitrogen removal occurs in the streams, then practices that reduce nitrogen loss at the field scale would be most efficient in fields least affected by in-stream nitrogen losses.

\section{OBJECTIVES}

The objectives of this study were to: (1) identify and quantify each nitrogen input and output to an overall nitrogen budget of a forest stream reach, (2) compare groundwater and stream flow nitrogen concentrations, (3) compare storm flow and base flow nitrogen concentrations, and (4) quantify nitrogen removal/retention resulting from in-stream processes by calculating a mass balance.

\section{NitROGEN INPUTS AND OUTPUTS}

Nitrogen inputs to surface waters are point or diffuse (nonpoint) sources (Owens et al., 1972). Point sources include sewage effluents, industrial wastes, and other sources that have a distinct origin such as an outlet pipe. Point sources were not present within the study area and will not be discussed further. The diffuse sources can be divided into three categories: hydrological sources, allochthonous sources, and 
autochthonous sources (Triska et al., 1984). Hydrologic sources can be subdivided into precipitation (Seely et al., 1998), throughfall (Miller et al., 1998), groundwater (Triska et al., 1984), and surface runoff (Cooke and Cooper, 1988). Allochthonous sources are the particulate organic inputs from the adjacent terrestrial environment (litterfall and lateral movement, i.e., litterfall that has previously fallen to the forest floor and been retransported by wind or runoff) as a source of fixed carbon and nutrients for in situ biological processes (Triska et al., 1984; Cooke and Cooper, 1988). Autochthonous sources are the in-stream production of carbon (photosynthesis) and nitrogen (nitrogen fixation) (Triska et al., 1984).

Nitrogen can be permanently removed from a forested stream in one of four ways: it can be released to the atmosphere via denitrification (Seitzinger, 1988; Triska et al., 1984), lost to insect emergence (Meyer et al., 1981), discharged at the mouth of the stream (Triska et al., 1989), or removed with dredge material during intermittent dredging. Canal cleaning operations such as dredging are intermittent. Dredging removes a thick layer of organic sediment and litter, which accumulate over time. This layer contains a large amount of organic nitrogen and ammonium within the pore water. Emergence drift is the removal of nitrogen from a stream due to insect emergence from the stream. Insects that go through their immature stages within the stream utilize nutrients as they grow and develop, leaving when they mature (Meyer et al., 1981).

\section{Site DesCription}

The study site was located in Washington County, near Plymouth, in the coastal plain of North Carolina (fig. 1). The 10,000 ha watershed drains into Albemarle Sound through an $8 \mathrm{~km}$ stretch of Kendrick's Creek. A section of the drainage network located in the 4000 ha tract of managed pine forest (Parker Tract) in the southern portion of the watershed was the study site.

The soils in the Parker Tract are primarily organic soils of the Belhaven series (loamy, mixed, dysic, thermic Terric Medisaprists) and Pungo series (dysic, thermic Typic Medisaprists) with some mineral soils of the Portsmouth series (fine-loamy over sandy or sandy-skeletal, mixed, thermic Typic Umbraquults) and Cape Fear series (clayey, mixed, thermic Typic Umbraquults) being present to a lesser extent (SCS, 1981). These soil series, characterized as very poorly drained with loamy subsoil, are prevalent in the lower coastal plains of North Carolina.

\section{FIELD DESCRIPTION}

A $1900 \mathrm{~m}$ section of a forest drainage canal in the Parker Tract (from S0 to S3 in fig. 1) was selected for the study. The canal averaged $4 \mathrm{~m}$ in top width, $1.4 \mathrm{~m}$ in depth, with side slopes of $1: 1$ and an overall bottom slope of 0.0003 . A litter layer (approx. $4 \mathrm{~cm}$ thick) and organic layer (approx. $20 \mathrm{~cm}$ thick) covered the bottom of the canal. Below approximately $20 \mathrm{~cm}$ lies a thick sand layer underlain by tight sandy clay, which was considered impermeable. This is a typical forest drainage canal description for this area. All existing lateral field ditches were plugged by filling a $4 \mathrm{~m}$ section with packed topsoil and rerouting to the opposite end to create a continuous reach with no surface water sources except for upstream inflow ( $\mathrm{S} 0$ in fig. 2). The canal was constructed during or prior to the 1960s to lower groundwater levels and improve

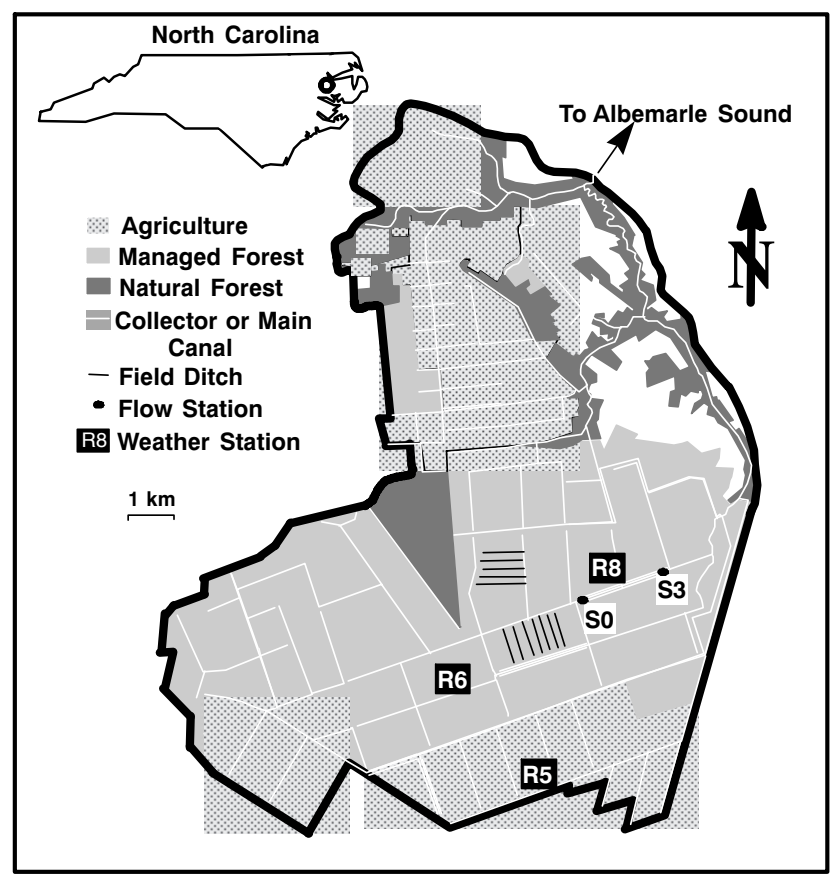

Figure 1. Location of Parker Tract watershed and canal study site in the lower coastal plain of North Carolina.

trafficability and soil conditions for timber production. The canal is dredged as needed to manage drainage. The canal was not cleaned out during the study period or for at least five years prior. The soil removed during initial construction was placed on the north side of the canal to form an access road. The south side is composed of a combination of planted pine, mixed natural pine and hardwood, and natural hardwood stands (approx. 50\%, 25\%, and 25\% of the canal study length, respectively; fig. 2). The canal itself has a several-meterwide strip of hardwoods lining both banks that overhangs the canal, shading it most of the year. During the winter, sunlight potentially strikes the water surface, but the sun at this time of year is low in the southern sky and is blocked by the forest along the southern bank of the canal. This canal normally flows from late fall (December) through mid-spring (April to May). In some years, flow will occur during summer and early fall in response to heavy rains from tropical storms or repeated convective showers.

\section{Methods}

Rainfall data were collected within $1 \mathrm{~km}$ of the study canal using a Hobo tipping-bucket rain gauge (R8 in fig. 1). Throughfall inputs were measured using three throughfall collectors. The three collectors were located along the length of the study canal on posts approximately $2 \mathrm{~m}$ above the water surface midpoint in the canal (fig. 2). Each collector consisted of a pair of $15 \mathrm{~cm}$ diameter funnels, which directed throughfall into two separate $2 \mathrm{~L}$ collection bottles. The funnels were screened with a $0.7 \mathrm{~mm}$ fiberglass mesh to remove larger material. The two collection bottles were located in separate, insulated, dark chambers. A manual rainfall gauge placed on the collector recorded total throughfall for each sample period. Throughfall samples were collected weekly during the flow period and monthly during the non-flow period. The bottle contents were thoroughly mixed prior to re- 


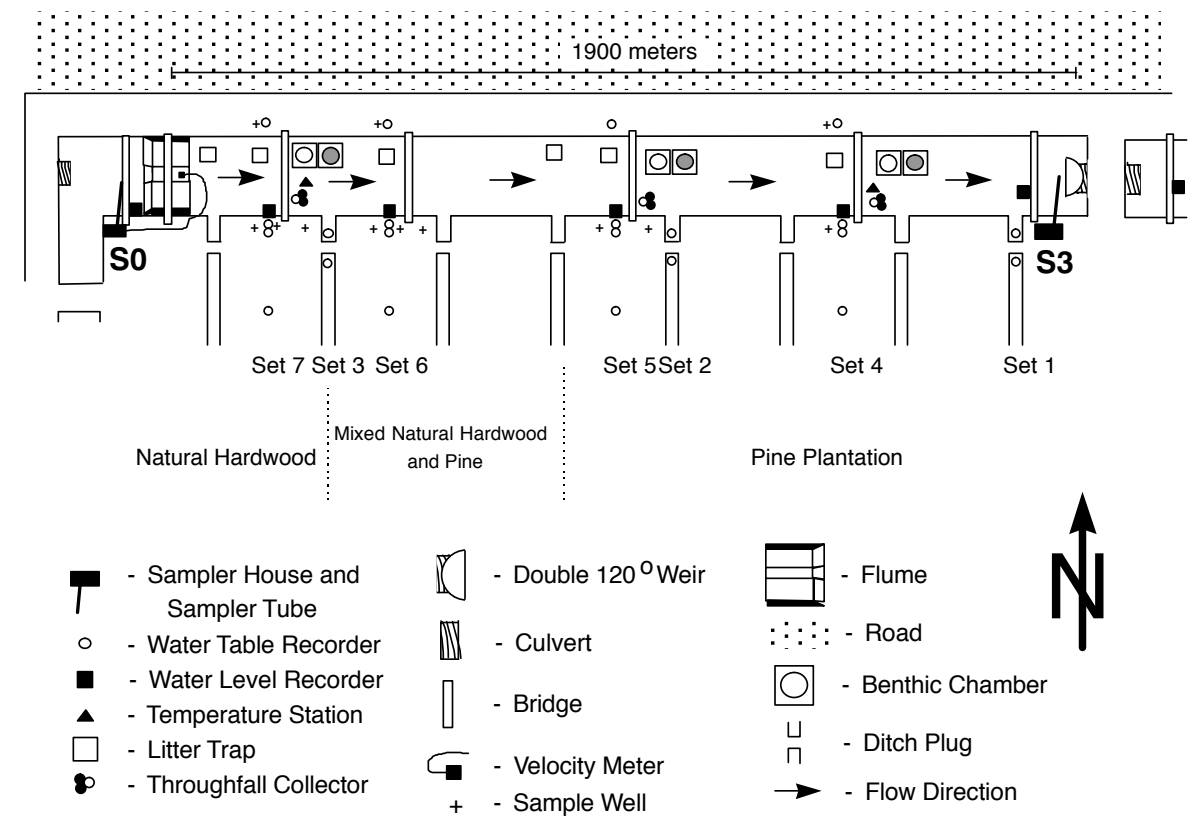

Figure 2. Study canal and equipment location.

moving a sample. During periods of low throughfall, the contents of the two collection bottles were combined into a single sample. Any remaining throughfall was discarded. The collection bottles were rinsed and acid was added to preserve the next sample. Throughfall inputs to the canal were calculated by total volume $\left(\mathrm{m}^{3}\right.$, throughfall times average water surface area in the canal) times concentration $\left(\mathrm{kg} \mathrm{m}^{-3}\right)$ for each rainfall event. Timing of rainfall events was determined at the $\mathrm{R} 8$ rain gauge (fig. 1). If more than one rainfall event occurred between throughfall samplings, the volume and nutrient mass for each event were calculated as percentages of each event. Totals were summed on a daily basis.

Groundwater was sampled from 12 wells, four within each of the three forest types (fig. 2). Each well was located $1 \mathrm{~m}$ from the canal's edge and installed to a depth of $2 \mathrm{~m}$, with the bottom $1.5 \mathrm{~m}$ screened. Samples were taken weekly in conjunction with throughfall. Samples were only taken during flow periods, as the water table rapidly dropped below the well depth in the absence of flow. Each well was bailed twice and allowed to refill prior to sampling. Samples were frozen immediately.

Water table recorders were placed $1 \mathrm{~m}$ from the canal edge on both the north and south sides (fig. 2). Water level recorders were placed within the canal to directly measure water elevation. Water table and water level elevations were recorded every $5 \mathrm{~min}$. Canal water level and groundwater level were used in Darcy's equation (eq. 1) to calculate groundwater flow into/from the canal from/to the forested fields and under the forest road:

$$
Q=K A \Delta h / L
$$

where

$$
\begin{aligned}
Q= & \text { flow rate }\left(\mathrm{m}^{3} \mathrm{~s}^{-1}\right) \\
\Delta h= & \text { head loss }(\mathrm{m}) \text { between the water level recorder on the } \\
& \text { bank and within the canal } \\
L= & \text { length of travel }(\mathrm{m}) \\
A= & \text { cross-sectional area of flow }\left(\mathrm{m}^{2}\right) \\
K= & \text { hydraulic conductivity }\left(\mathrm{m} \mathrm{s}^{-1}\right) .
\end{aligned}
$$

Hydraulic conductivities estimated for two neighboring fields (Diggs, 2004) were used to calculate flow from the fields bordering the study canal section. Water movement through the field ditch plugs was to be estimated at three locations similar to groundwater flow. However, due to drought, water depths within the study canal never reached the point where the plugs restricted water flow. Water surface elevations measured by two water level recorders placed on either side of the plug were used in Darcy's equation to determine flow volume and direction through the plug. There was uncertainty in the flow calculations due to the spatial variability of the hydraulic conductivities found within soils, especially in forested soils where root channels and high porosity result in preferential flow paths.

Groundwater nutrient contributions to the canal were determined by multiplying calculated groundwater flows $\left(\mathrm{m}^{3}\right)$ by their associated well concentrations $\left(\mathrm{kg} \mathrm{m}^{-3}\right)$ and summed daily. Sample concentrations used in calculations were from midpoint to midpoint between samplings. Nitrogen transformations between the well location and the canals surface water were considered minimal due to the short transport path $(1 \mathrm{~m})$ and high soil conductivity (400 to $700 \mathrm{~cm} \mathrm{~h}^{-1}$ ).

Upstream inflow to the study reach was estimated in a flume structure using a Doppler flowmeter (Starflow, Unidata Pty Ltd., Perth, Australia; $2 \%$ accuracy with $1 \mathrm{~mm} \mathrm{~s}^{-1}$ resolution). The flume structure provided a known crosssectional area to calculate flow as well as an unobstructed flow path for the meter. Average stage and velocity readings at the center of the channel were automatically recorded every $10 \mathrm{~min}$. Doppler flowmeter velocities were converted to average channel velocities using the relationship $Y=0.7893 X$ with an $\mathrm{R}^{2}$ of 0.96 , where $X$ is the Doppler flowmeter velocity and $Y$ is the calculated average velocity within the flume. The relationship was developed by comparing Doppler flowmeter velocities to average flow velocities determined using manual velocity measurements and the velocity-areaintegration method (Roberson et al., 1988) for the same periods. Manual measurements were taken using a portable water current meter (model 201, Marsh McBirney, Inc., Frederick, 
Md.) at 0.60 the flow depth from the water surface during shallower flow depths $(<1 \mathrm{~m})$ and at 0.2 and 0.8 the flow depth at deeper flow depths $(>1 \mathrm{~m})$ at equally spaced locations across the flume.

Discrete water quality samples were taken using an automatic sampler (model 900, Sigma, Loveland, Colo.) at S0 and S3. The sampler was connected to a Blue Earth microprocessor and a water level recorder to trigger the sampler and record stage and time of sample. Samples were flowproportional during normal flow. During rain events, the sampling regime switched to a timed mode based on the time to peak, taking samples every $2 \mathrm{~h}$ on the rising hydrograph limb and every $6 \mathrm{~h}$ on the falling limb until flow returned to a threshold level. Total inflow nutrient loads were calculated on a 10 min basis by multiplying flow volumes $\left(\mathrm{m}^{3}\right)$ by nutrient concentrations $\left(\mathrm{kg} \mathrm{m}^{-3}\right)$ and summed daily. Sample concentrations used for calculations were from midpoint to midpoint between samplings.

Surface runoff was not measured because surface storage was large $(>0.2 \mathrm{~m})$ and rainfall either infiltrated immediately or was stored until infiltration.

Litter and lateral inputs were measured as one input. Samples were collected at five locations along the study canal in $0.5 \times 0.5 \mathrm{~m}$ litter traps screened with $0.7 \mathrm{~mm}$ fiberglass mesh floating in the canal. The traps were tethered to the bank to intercept litter as well as lateral material prior to entering the canal. Litter material was removed weekly and air-dried. Samples were then oven-dried, weighed, ground, and analyzed for nitrogen content (Perkin Elmer, 1988). Litterfall nutrient contributions to the canal were calculated by multiplying sample nutrient content $\left(\mathrm{kg} \mathrm{m}^{-2}\right)$ by average water surface area $\left(\mathrm{m}^{2}\right)$ present in the canal for each sampling period. The litterfall input rate was assumed to be evenly distributed over the sampling period and summed daily.

Autochthonous inputs were considered insignificant due to canopy light interception, which discouraged plant growth. Other studies (e.g., Meyer et al., 1981; Triska et al., 1982; Fisher and Likens, 1973) found that forested streams are almost entirely devoid of autochthonous inputs. Emergent output was also considered insignificant as other studies found that the nutrient losses from this vector in forested streams were negligible (e.g., Triska et al., 1984; Meyer et al., 1981).

Outflow from the study canal was determined using both upstream and downstream stages of a double $120^{\circ} \mathrm{V}$-notch weir structure instrumented with a Blue Earth microprocessor, a water level recorder, and a Sigma 900 automated sampler. Flow data were recorded at a maximum time interval of $1 \mathrm{~h}$ during base flow and as often as every 3 min during rapid changes in flow due to rainfall events. The bottom of the weir was located at an elevation to minimize the amount of water held back by the structure as well as to reduce the potential for submergence. The weir equation was calibrated using a Doppler flowmeter in the outflow pipe. The Doppler velocity was calibrated using manual velocity measurements, as described previously for calibrating the flume flows. The Doppler flowmeter and the weir flow calculations had a 1-to-1 relationship after calibration of the flow discharge coefficient, leading to approximate accuracy of $2 \%$ of the measured value. Total outflow and nutrient loads were calculated daily by multiplying flow volumes $\left(\mathrm{m}^{3}\right)$ by nutrient concentrations $\left(\mathrm{kg} \mathrm{m}^{-3}\right)$. Sample concentrations used for calculations were from midpoint to midpoint between samplings.
Dissolved oxygen, $\mathrm{pH}$, and temperature at mid-depth of the water column of the inflow and outflow were taken weekly using a multi-parameter water quality monitor (model 610-D, YSI, Inc., Yellow Springs, Ohio). These parameters were not taken in the groundwater wells.

Water quality samples were acid fixed (except groundwater samples) to prevent nitrogen transformation while the samplers awaited collection in accordance with EPA Method 353.2. Acid was not added to the groundwater samples as they were immediately frozen. Natural $\mathrm{pH}$ for organic soils on the site is less than $\mathrm{pH} 4.3$ (Diggs, 2004). All water samples were placed (unfiltered) in a freezer on site and kept frozen until analysis. Samples were frozen unfiltered, as the number of samples made it impossible to filter them in the field prior to freezing. Studies conducted by Kotlash and Chessman (1998) and Dore et al. (1996) showed little to no difference between frozen filtered and unfiltered samples when analyzed for ammonium, nitrate/nitrite, and total Kjeldahl nitrogen (TKN). Prior to analysis, all samples were thawed, shaken, and except for the organic nitrogen samples, filtered through a 0.45 micron filter (Supor-450, Gelman Laboratory). Each sample was analyzed for ammonium, nitrate/nitrite, organic nitrogen (TKN minus ammonium), and chloride. Ammonium concentrations were determined by mixing the sample with an alkaline solution to release ammonia and read at $590 \mathrm{~nm}$ using a Lachat continuous flow analyzer $\left(0.1 \mathrm{mg} \mathrm{N} \mathrm{L} \mathrm{N}^{-1}\right.$ minimum detection limit, $\pm 0.5 \%$ precision per Lachat manual; APHA, 1989). Nitrate/nitrite concentrations were determined by cadmium reduction and read at $520 \mathrm{~nm}$ using a Lachat continuous flow analyzer (0.1 $\mathrm{mg} \mathrm{N} \mathrm{L}^{-1}$ minimum detection limit, $\pm 0.5 \%$ precision per Lachat manual; APHA, 1989). TKN concentrations (including particulates) were determined following digestion of unfiltered samples as ammonium using a Lachat continuous flow analyzer $\left(0.1 \mathrm{mg} \mathrm{N} \mathrm{L} \mathrm{N}^{-1}\right.$ minimum detection limit, $\pm 0.5 \%$ precision per Lachat manual; APHA, 1989). Chloride concentrations were determined using a chloride meter (0.1 $\mathrm{mg} \mathrm{N} \mathrm{L}^{-1}$ minimum detection limit, $\pm 0.05 \mathrm{mg} \mathrm{L}^{-1}$ precision; APHA, 1989).

A mass balance was used to account for flow volume and the different nitrogen species for the canal's study reach (eq. 2):

$$
\text { Output }=\sum \text { Inputs }- \text { Losses }
$$

where

$$
\begin{aligned}
& \text { Output }=\text { volume at the outlet }\left(\mathrm{m}^{3}\right) \\
& \text { Inputs = upstream inflow, rainfall/throughfall, and } \\
& \text { groundwater }\left(\mathrm{m}^{3}\right)
\end{aligned}
$$
tion 3:

$$
\text { Output }=\sum \text { Inputs }+ \text { Transformations }
$$

where
Output
Inputs
$=$ load at the outlet $(\mathrm{kg})$
= loads from upstream inflow, rainfall/ throughfall, groundwater, and litterfall (kg)
Transformations $=$ mineralization $(+)$, nitrification $(+)$, and denitrification $(-)$. Volumes, nitro- gen loads, and chloride loads were summed daily. 
Concentration variability for throughfall, groundwater, and litterfall/lateral movement were determined using the standard deviation of all the samples collected over the sampling period and multiplying by 1.96 to create the $95 \%$ confidence interval. Variability of the inflow and outflow volumes was assumed to be $2 \%$ based on the manufacturer's stated accuracy of the flowmeter, and were summed over the study period and multiplied by 1.96 to create the $95 \%$ confidence interval. The $2 \%$ deviations were squared, summed, and the square root of the sum was taken to get the standard deviation for both the total inflow and total outflow. Each load is a product of concentration times the associated flow volume, where the variability is determined by squaring the fractional standard deviations, adding them, taking the square root of the sum, and multiplying by the product of the concentration and flow volume: $\mathrm{SD}_{\text {load }}=$ load $\times\left\{\sum\left(\mathrm{SD}_{\text {flow }} / \mathrm{flow}\right)^{2} \times\right.$ $\left.\left(\mathrm{SD}_{\text {concentration }} / \text { concentration }\right)^{2}\right\}^{0.5}$. Each total load variability was determined by squaring the fractional standard deviations, adding them, and taking the square root of their sum: $\mathrm{SD}_{\text {total load }}=\left\{\sum\left(\mathrm{SD}_{\text {load }}\right)^{2}\right\}^{0.5}$. The $\mathrm{SD}_{\text {total load }}$ was then multiplied by 1.96 to form the $95 \%$ confidence interval for the total load.

Chloride was used as a conservative tracer, and concentrations were measured for all hydrologic inputs and outputs. Closure of the chloride mass balance indicates that all the inputs and outputs were accurately estimated. Chloride was used because it is highly mobile and not readily adsorbed onto surfaces or incorporated into secondary minerals (Peters and Ratcliffe, 1998), relative to the time periods of this study.

\section{RESUlts AND Discussion}

\section{HYDROLOGIC BUDGET}

Flow in the canal occurred from 14 February to 1 May in 2001 and from 22 January to 14 May in 2002. Discussion of the results is confined to the flow period. When flow was not occurring, the only measured parameters were monthly litterfall/lateral movement and throughfall. Drought conditions occurred both years, with 2001 being more severe.

The 2001 hydrologic budget closed to within $0.1 \%$ (a $204 \mathrm{~m}^{3}$ deficit) (table 1). Upstream inflow was the major hydrologic source at 213,000 $\mathrm{m}^{3}$ (approx. 96.3\%) of the net total input from an approximately 700 ha drainage. Inflow variability at $\mathrm{S} 0$ was $\pm 118 \mathrm{~m}^{3}$. Throughfall was a minor hydrologic component at $804 \mathrm{~m}^{3}$ (approx. 0.4\%). Throughfall variability was low, $\pm 39 \mathrm{~m}^{3}$ or $\pm 5 \%$, due to frontal boundaries that caused relatively uniform rain to the $1900 \mathrm{~m}$ study reach. In addition, rainfall during 2001 produced similar throughfall totals with little variability (fig. 3). Subsurface flow was also minor at 7,484 $\mathrm{m}^{3}$ (approx. $3.4 \%$ ), up to day 70 , after which water flow to the surrounding soils resulted in a net loss of $26,600 \mathrm{~m}^{3}$. Subsurface flow variability was high, $\pm 9,610 \mathrm{~m}^{3}$ or $\pm 36 \%$. This high variability was due to several factors. First was the natural variability in hydraulic conductivity of soils due to macropores resulting from root channels or other buried organic debris. Second, and more important, was the presence of a canal on the north side of the road running along the study canal. This canal caused large amounts of flow from the study canal under the road, resulting in a large difference in the calculated flows from the wells on the north side of the canal and those bordered by forested fields on the south side of the canal. Variability of subsurface flow to and from the forested fields to the south was $\pm 82 \mathrm{~m}^{3}$.

The daily inflow vs. outflow hydrograph for 2001 (fig. 3) shows close agreement with the exception of days 70 to 80 . A minimal offset between the inflow and outflow hydrograph can be seen in 2001, with outflow lagging inflow. This was due to travel time within the canal section, which ranged from $2.9 \mathrm{~h}$ during base flow to $1.8 \mathrm{~h}$ during event peaks. The exception between the daily hydrographs, between days 70 and 80 , was due to measurement errors of water loss to the soil profile. The two hydrographs become very similar after day 83 as monitoring wells were installed on the north side of the canal to monitor losses under the road. These wells were not previously installed, as the two canals, on the north and south sides of the road, were connected through a culvert just upstream. It was assumed that the water elevations of the two would be similar, resulting in no flows under the road. Prior to day 70, groundwater flows to and from the canal were minimal (fig. 4). Subsequent higher water losses from the canal to the soil profile after day 70 was due mainly to two factors. The first factor was rapid lowering of the water level in the north ditch. The north ditch is deeper and free flowing (the downstream structure on the study canal is a weir, which will hold water levels higher than a free flowing ditch, $0.3 \mathrm{~m}$ at the weir in this case). Second, rising spring temperatures after day 90 increased evapotranspiration, keeping the water table elevation below that of the canal (Appelboom, 2004). The similarity of the two hydrographs after day 83 was due to a better accounting for flow under the road after installation of additional water level recorders. Unmeasured flow under the road, particularly between days 70 and 80, was a significant source of error in the 2001 water balance even though the overall budget variability was very high $\left( \pm 9613 \mathrm{~m}^{3}\right)$.

The 2002 hydrologic budget closed to within $2.5 \%$ (an $8,280 \mathrm{~m}^{3}$ deficit) (table 2). Upstream inflow dominated,

Table 1. Input and output flow volumes, nitrogen loads, and chloride load to the study canal section during the 2001 flow period. Given ranges are with a $95 \%$ confidence interval: average \pm 1.96 (SD).

\begin{tabular}{lccccc}
\hline Input/Output & $\begin{array}{c}\text { Volume } \\
\left(\mathrm{m}^{3}\right)\end{array}$ & $\begin{array}{c}\text { Nitrate-N } \\
(\mathrm{kg})\end{array}$ & $\begin{array}{c}\text { Organic-N } \\
(\mathrm{kg})\end{array}$ & $\begin{array}{c}\text { Total N } \\
(\mathrm{kg})\end{array}$ & $\begin{array}{c}\text { Chloride } \\
(\mathrm{kg})\end{array}$ \\
\hline Inflow at S0[a] & $213,000 \pm 118$ & $234 \pm 0$ & $337 \pm 0$ & $571 \pm 0$ & $2400 \pm 1$ \\
Throughfall & $804 \pm 39$ & $0.6 \pm 0.2$ & $1.0 \pm 0.2$ & $1.6 \pm 0.3$ & $2.8 \pm 0.4$ \\
Flow to/from fields & $-26,600 \pm 9,610$ & $-19.4 \pm 31.9$ & $-33.9 \pm 26.7$ & $-53.3 \pm 41.6$ & $-173 \pm 161$ \\
Litterfall & -- & -- & $8.5 \pm 3.5$ & $8.5 \pm 3.5$ & -- \\
Outflow at S3[a] & $187,000 \pm 211$ & $218 \pm 3$ & $284 \pm 4$ & $502 \pm 5$ & $2290 \pm 22$ \\
Difference (output-input) & $-204 \pm 9613$ & $2.8 \pm 32.8$ & $-28.6 \pm 27.2$ & $-25.8 \pm 42.0$ & $60.2 \pm 162.5$ \\
\% Difference (1 - input/output) $\times 100$ & $-0.1 \%$ & $1.3 \%$ & $-10.1 \%$ & $-5.1 \%$ & $2.6 \%$ \\
\hline
\end{tabular}

[a] Total variability based on $2 \%$ daily calculated variability summed over the flow period. 


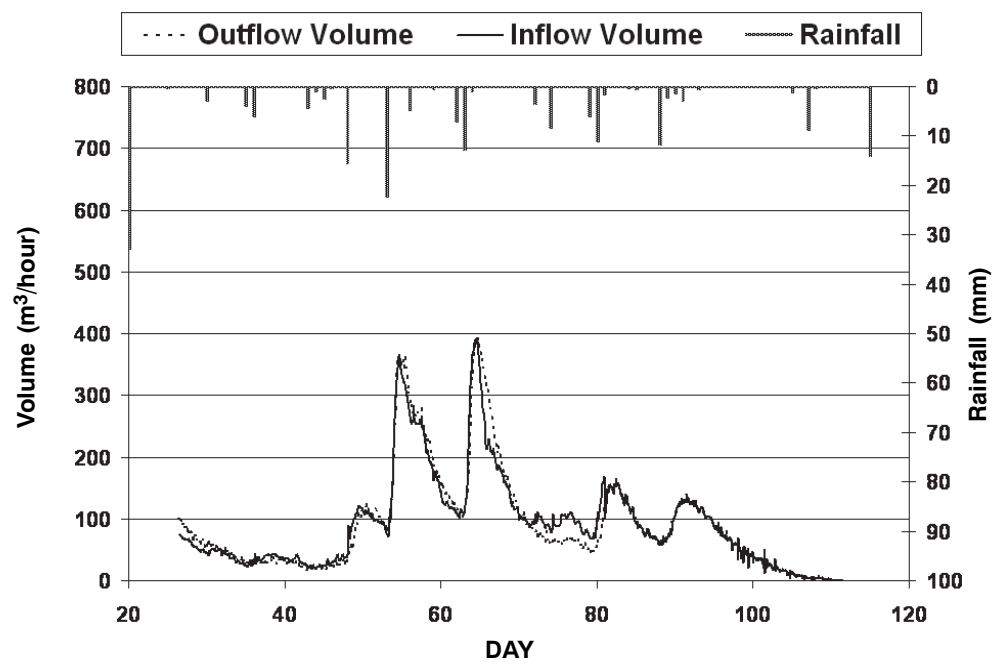

Figure 3. Daily outflow at $S 3$ and sum of inflows (inflow at $S 3$ + rainfall + groundwater flow) hydrographs for the flow period 14 February to 1 May in 2001.

accounting for 323,000 $\mathrm{m}^{3}$ (approx. 98.2\%) of net hydrologic input to the reach. Inflow variability at $\mathrm{S} 0$ was $\pm 226 \mathrm{~m}^{3}$. Throughfall was minor at $1,270 \mathrm{~m}^{3}$ (approx. 0.4\%). Throughfall variability was higher in $2002\left( \pm 186 \mathrm{~m}^{3}\right.$ or $\pm 15 \%$ ) than in 2001 due to greater variability in the total rainfall (fig. 5). Subsurface flow was also minor at 5,010 $\mathrm{m}^{3}$ (approx. 1.5\%). Subsurface flow variability was low, $\pm 123 \mathrm{~m}^{3}$ or $\pm 2.5 \%$, because in 2002 the rainfall events occurred such that the water surface elevation in the north canal did not vary much from that of the study canal, minimizing flow beneath the road (fig. 6). Calculated flows to and from the soil profiles both north and south of the study reach were similarly low, eliminating the large differences between the two sides seen in 2001. The daily inflow and outflow hydrographs for 2002 (fig. 5) show a similar offset as in 2001, which was expected.

The daily groundwater flows to and from the canal were minimal in 2002 (fig. 6). There was a period of unaccounted differences between the two hydrographs starting around day 100 , when the sum of inflows exceeded outflows. This indicates an error in the water budget during this period of increasing temperature and beginning of the spring growth flush of 2002 (Appelboom, 2004). As in 2001, the water table was drawn down below the canal elevation by evapotranspiration. This assumption is supported by the occurrence of an inflow peak on around day 115 but not an outflow peak. During summer, when continuous flow is typically absent, substantial inflow at $\mathrm{S} 0$ has been observed after large rainfall events, which never reaches S3. This can be seen in figure 5, where outflow at S3 had ceased on day 120 while inflows continued. Thus, the error in closing the 2002 water budget was in the measurement of outflows between days 100 and 120.

\section{Chloride Budget}

The 2001 daily chloride load followed the pattern of the inflow and outflow hydrographs, with outflow lagging by the varying travel times through the reach (fig. 7). The lower daily chloride load in the outflow between days 70 and 80 was due to the unaccounted water loss under the road. The 2001 chloride mass balance had an outflow surplus of 60.2 $\pm 162.5 \mathrm{~kg}$, or $2.6 \%$ (table 1 ). The throughfall chloride input was minor compared to upstream inflow $(2.8 \mathrm{~kg}$, or $0.1 \%$, and $2400 \mathrm{~kg}$, or $99.9 \%$, of the budget, respectively). Groundwater

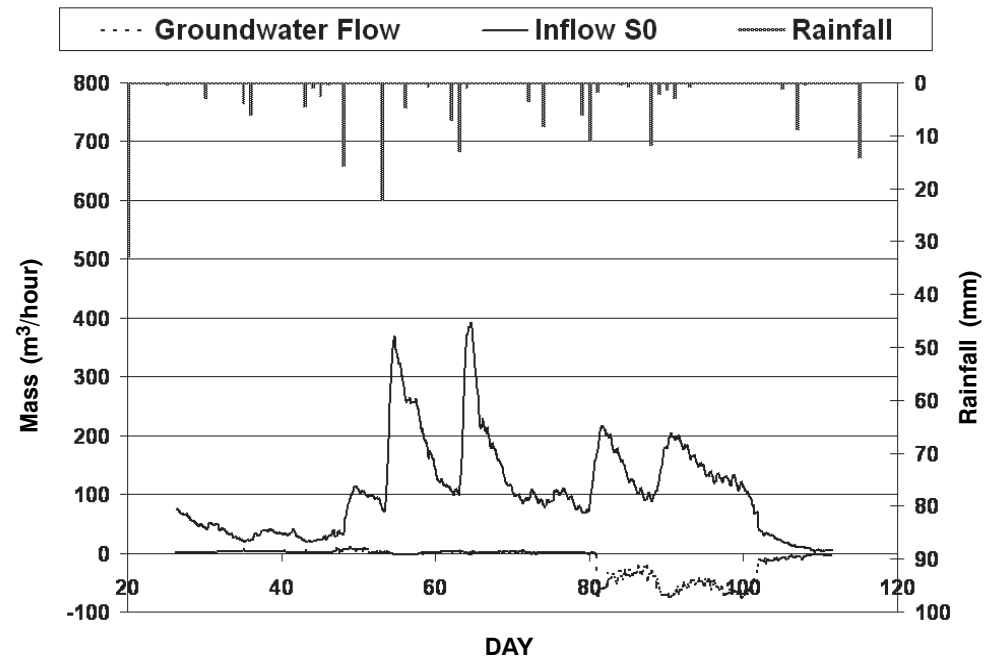

Figure 4. Daily canal flow (inflow at S0) and measured groundwater input and output to the canal for the flow period 14 February to 1 May in 2001. 
Table 2. Input and output flow volumes, nitrogen loads, and chloride load to the study canal section during the 2002 flow period. Given ranges are with a $95 \%$ confidence interval: average \pm 1.96 (SD).

\begin{tabular}{|c|c|c|c|c|c|}
\hline Input/Output & $\begin{array}{l}\text { Volume } \\
\left(\mathrm{m}^{3}\right)\end{array}$ & $\begin{array}{l}\text { Nitrate-N } \\
(\mathrm{kg})\end{array}$ & $\begin{array}{l}\text { Organic-N } \\
(\mathrm{kg})\end{array}$ & $\begin{array}{c}\text { Total N } \\
(\mathrm{kg})\end{array}$ & $\begin{array}{c}\text { Chloride } \\
(\mathrm{kg})\end{array}$ \\
\hline Inflow at $\mathrm{SO}^{[\mathrm{a}]}$ & $323,000 \pm 226$ & $894 \pm 1$ & $502 \pm 0$ & $1396 \pm 1$ & $3157 \pm 2$ \\
\hline Throughfall & $1,270 \pm 186$ & $0.6 \pm 0.2$ & $2.7 \pm 0.8$ & $3.3 \pm 0.8$ & $1.8 \pm 0.8$ \\
\hline Flow to/from fields & $5,010 \pm 123$ & $7.2 \pm 13.7$ & $8.1 \pm 18.8$ & $15.3 \pm 23.3$ & $73 \pm 73$ \\
\hline Litterfall & -- & -- & $8.1 \pm 2.5$ & $8.1 \pm 2.5$ & -- \\
\hline Outflow at $\mathrm{S} 3$ [a] & $321,000 \pm 354$ & $924 \pm 1$ & $534 \pm 1$ & $1458 \pm 2$ & $2712 \pm 3$ \\
\hline Difference (output-input) & $-8,280 \pm 476$ & $22.2 \pm 13.8$ & $13.1 \pm 19.0$ & $35.3 \pm 23.6$ & $-519.8 \pm 73.1$ \\
\hline$\%$ Difference $(1-$ input/output $) \times 100$ & $-2.5 \%$ & $2.4 \%$ & $2.5 \%$ & $2.4 \%$ & $-19.2 \%$ \\
\hline
\end{tabular}

[a] Total variability based on $2 \%$ daily calculated variability summed over the flow period.

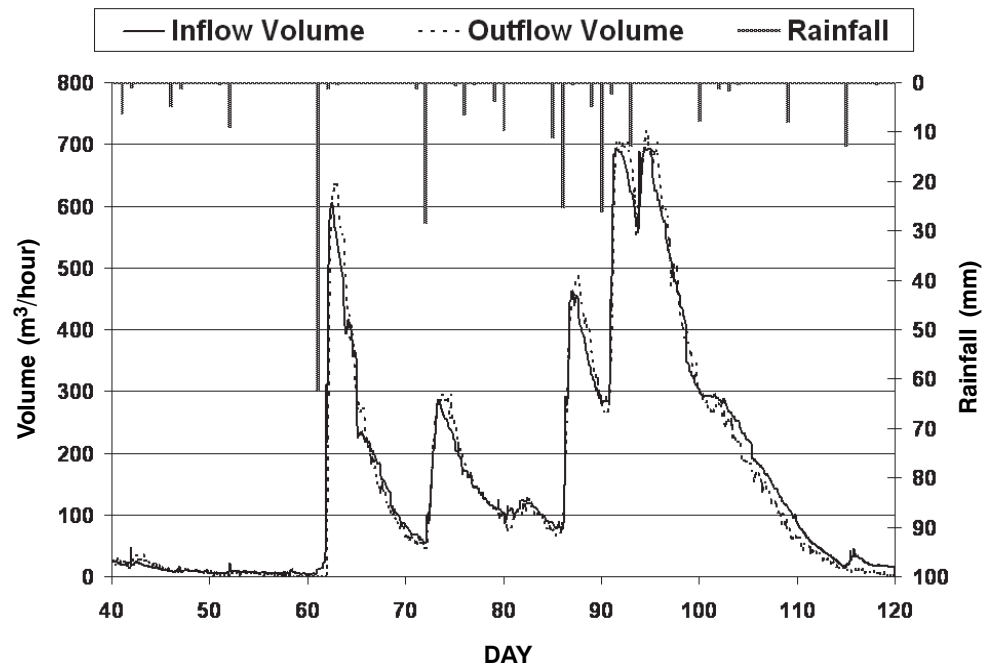

Figure 5. Daily outflow at S3 and sum of inflows (inflow at S3 + rainfall + groundwater flow) hydrographs for the flow period 22 January to 14 May in 2002.

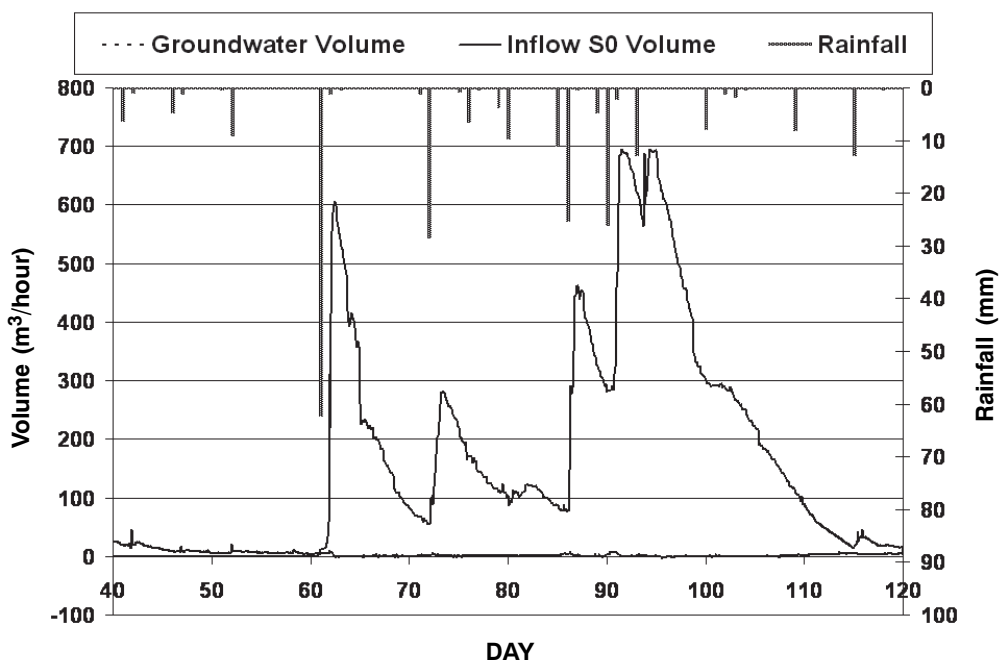

Figure 6. Daily canal flow (inflow at S0) and groundwater input and output to the canal for the flow period 22 January to 14 May in 2002.

chloride resulted in a net loss from the system of $173 \mathrm{~kg}$. The overall chloride budget surplus was due to a combination of the unclosed water balance and variability in groundwater and throughfall components $(38.5 \pm 35.9$ and $3.7 \pm 2.7 \mathrm{mg}$ $\mathrm{L}^{-1}$, respectively; table 3 ). Variability in throughfall chloride concentrations was due to variable chloride deposition from windblown ocean salts and differences in foliage interception (foliage holding chloride until rainfall washes it to the ground or canal surface).
Groundwater variability was due to the same factors as throughfall in that throughfall striking the ground infiltrates and recharges the groundwater carrying its associated chloride. It is also affected by groundwater transport. During high rainfall years, excess chlorides flush from the soil, lowering chloride concentrations. During low rainfall periods with little subsurface flow, as in 2001, chlorides accumulate, raising concentrations. The chloride load lost to the $204 \mathrm{~m}^{3}$ of unaccounted-for flow would equal $2.39 \mathrm{~kg}$ 


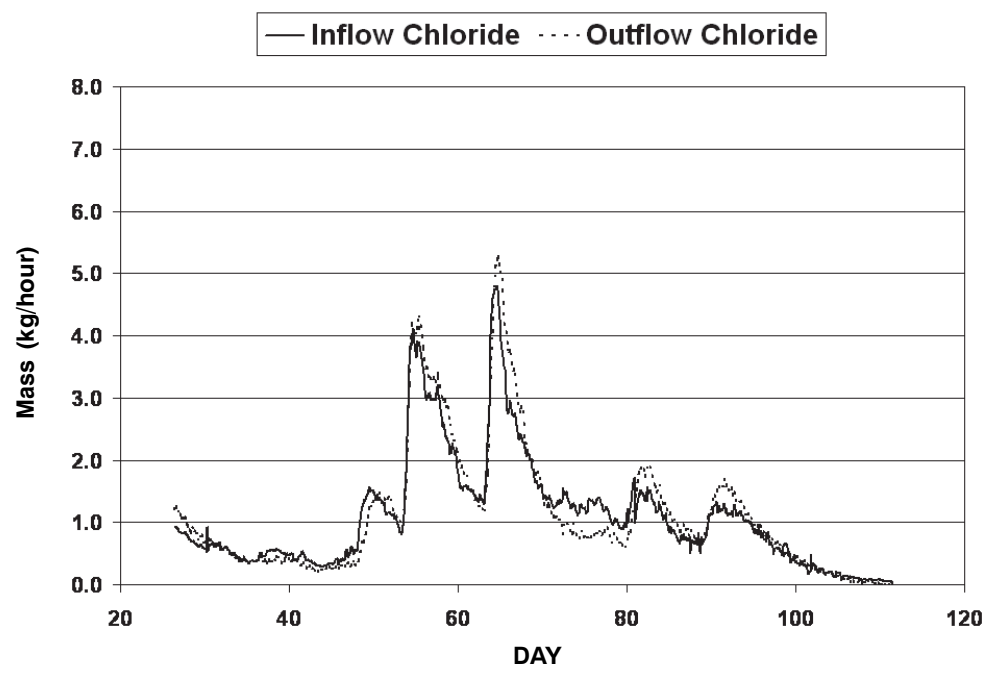

Figure 7. Daily inflow and outflow chloride loads for the flow period 14 February to 1 May in 2001.

(based on the flow-weighted average of both the inflow and outflow concentrations, 11.3 and $12.2 \mathrm{mg} \mathrm{L}^{-1}$, respectively, because it is chloride associated with surface water moving from the canal to the surrounding soil profile, as discussed previously), and if added to the surplus of the chloride budget (added because it is a loss to the system, reducing total inputs and increasing the chloride surplus at the outlet) would result in a total difference between inflows and outflows of $62.6 \mathrm{~kg}$. The $62.6 \mathrm{~kg}$ closure deficit in the 2001 chloride budget was within the total variability of the inputs and outputs, $\pm 162.5 \mathrm{~kg}$, and would not be considered significant. The net loss of chloride to the fields $(173 \mathrm{~kg}$ ) was primarily due to the net flow to the fields and under the road after day 70 .

Groundwater chloride concentrations in 2001 were 3 to 5 times greater than that of the canal water (fig. 8), but with the minimal flow from the soil profile they had little influence on the outflow concentrations. The groundwater chloride concentrations were not influenced by the waters from the canal since flow direction was primarily toward the canal. During the few periods of flow toward the soil profile, chloride concentrations were lower in groundwater (fig. 8). The major flows from the canal to the soil profile occurring after day 70 were under the road to the north, lowering chloride concentrations in those wells relative to the south wells. This contributed to the high variability in groundwater chloride concentrations.

Similar to 2001, the 2002 reach chloride load was dominated by upstream inflow (3157 $\mathrm{kg}$, or 97.7\%). Throughfall and groundwater were minor $(1.8 \mathrm{~kg}$, or $0.1 \%$, and $73 \mathrm{~kg}$, or $2.2 \%$, respectively). The 2002 chloride mass balance showed a large percentage, $19.2 \%(519.8 \pm 73.1 \mathrm{~kg})$, of unaccounted chloride loss from the reach (table 2). A portion of this deficit, $85.3 \mathrm{~kg}$, was due to the $2.5 \%$ error in the closing of the water balance, which left a $16.7 \%$ $(434.5 \mathrm{~kg})$ difference. This deficit was due to unexplained inflow concentrations, which were approximately $10 \%$ higher than outflow concentrations from days 47 to 63 and days 73 to 100 , figs. 9 and 10). This concentration difference, although unexplained, accounted for $256 \mathrm{~kg}$ of the total inflow - outflow difference, leaving a $178.5 \mathrm{~kg}$ chloride deficit, some of which can be attributed to the groundwater and throughfall variability $\left( \pm 14.3\right.$ and $\pm 1.8 \mathrm{mg} \mathrm{L}^{-1}$, respectively; table 4). Including total variability of the inputs and outputs $(73.1 \mathrm{~kg})$, a deficit of $105.4 \mathrm{~kg}(3.2 \%)$ remains. This remaining difference is most likely related to the differences in inflow and outflow concentrations.

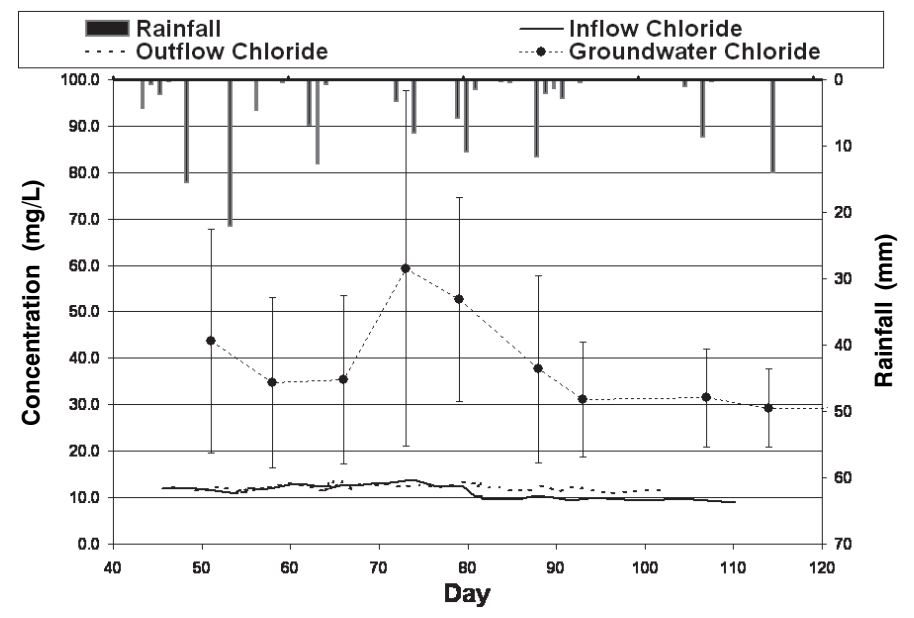

Figure 8. 2001 Chloride concentrations for inflow at S0, outflow at S3, and in groundwater (groundwater samples have a $95 \%$ confidence interval shown). 


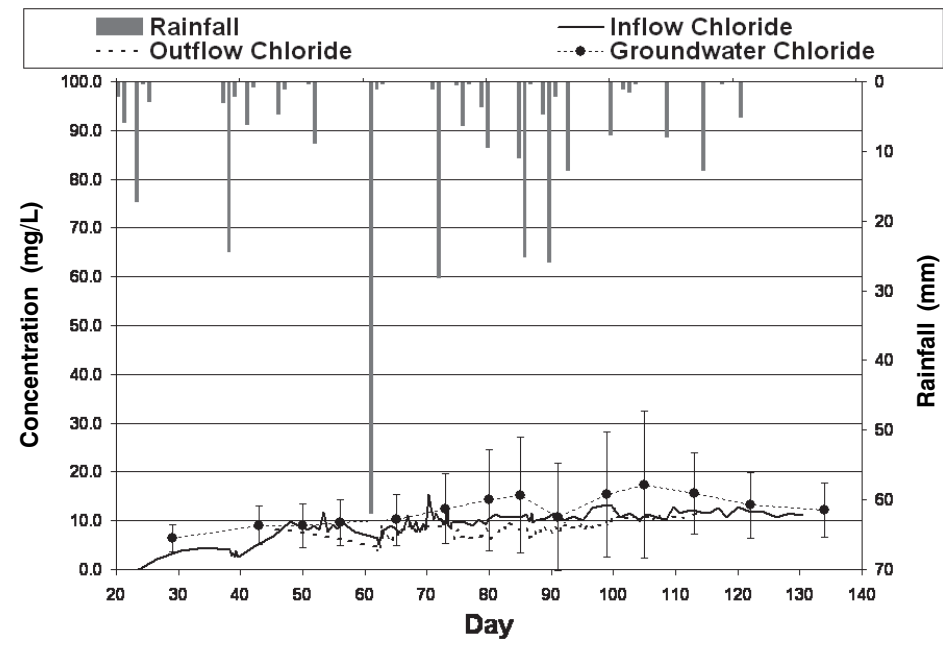

Figure 9. 2002 Chloride concentrations for inflow at S0, outflow at S3, and in groundwater (groundwater samples have a $95 \%$ confidence interval shown).

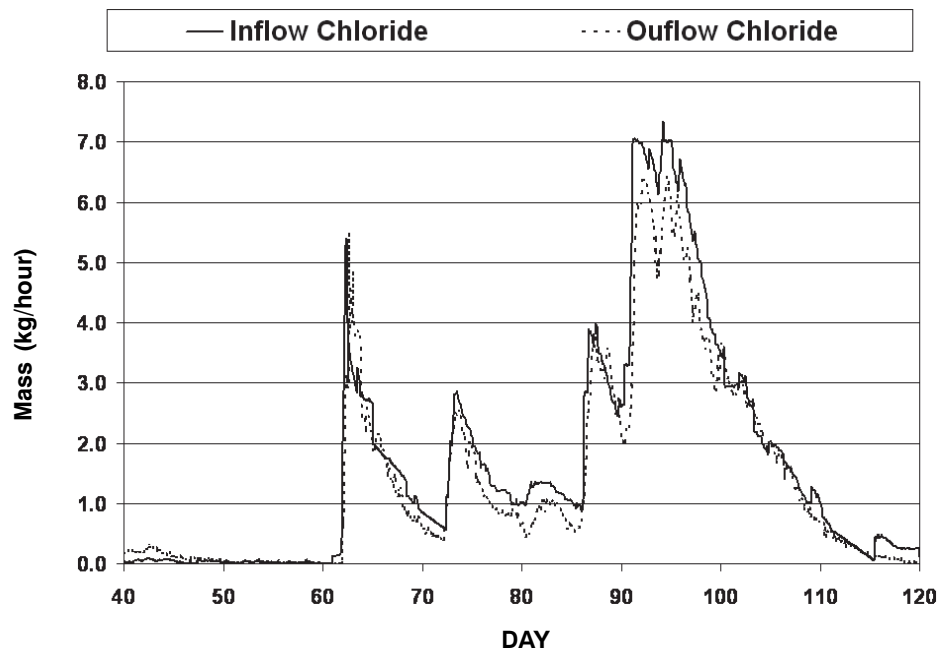

Figure 10. Daily inflow and outflow chloride loads for the flow period 22 January to 14 May in 2002.

Table 3. Input and output average nitrogen and chloride concentrations to the study canal section during the 2001 flow period. Given ranges are with a $95 \%$ confidence interval: average $\pm 1.96(\mathrm{SD})$.

\begin{tabular}{lccccc}
\hline Input/Output & $\begin{array}{c}\text { Ammonium } \\
\left(\mathrm{mg} \mathrm{L}^{-1}\right)\end{array}$ & $\begin{array}{c}\text { Nitrate-N } \\
\left(\mathrm{mg} \mathrm{L}^{-1}\right)\end{array}$ & $\begin{array}{c}\text { Organic-N } \\
\left(\mathrm{mg} \mathrm{L}^{-1}\right)\end{array}$ & $\begin{array}{c}\text { Total N } \\
\left(\mathrm{mg} \mathrm{L}^{-1}\right)\end{array}$ & $\begin{array}{c}\text { Chloride } \\
\left(\mathrm{mg} \mathrm{L}^{-1}\right)\end{array}$ \\
\hline Inflow at S0[a] & 0.08 & 1.1 & 1.6 & 2.7 & 1.3 \\
Throughfall[b] & $0.7 \pm 1.0$ & $0.8 \pm 0.6$ & $1.6 \pm 1.0$ & $3.1 \pm 1.6$ & $3.7 \pm 2.7$ \\
Flow to/from fields ${ }^{[\mathrm{b}]}$ & $0.7 \pm 0.6$ & $1.1 \pm 1.8$ & $1.7 \pm 1.4$ & $3.5 \pm 2.5$ & $38.5 \pm 35.9$ \\
Litterfall & -- & -- & -- & - & 1.7 \\
Outflow at S3[a] & 0.08 & 1.2 & 1.5 & 2.7 & 12.2 \\
\hline
\end{tabular}

[a] Concentrations are volume-weighted proportional averages for the flow period.

[b] Concentrations are averages of measured concentrations of samples taken during the flow period.

Groundwater chloride concentrations in 2002 were only 1 to 1.8 times that of the canal water (fig. 9). This was due to the lower throughfall chloride concentrations in 2002 compared to 2001 (1.9 and $3.7 \mathrm{mg} \mathrm{L}^{-1}$, respectively; tables 3 and 4). The difference between the two years was most likely due to the differences in the wind direction. The site is located $50 \mathrm{~km}$ to the northeast of Pamlico Sound, a large expanse of salt water, and $130 \mathrm{~km}$ to the north and west of the Atlantic Ocean. Weather records show that during 2001 the prevailing winds were from the south, averaging $9 \mathrm{~km} \mathrm{~h}^{-1}$, which would carry salt spray from both the Atlantic Ocean and Pamlico Sound over the site. During 2002, the prevailing winds were from the north, over the land, averaging $7 \mathrm{~km} \mathrm{~h}^{-1}$. The throughfall data for the two years support this explanation in that 2001 throughfall chloride concentrations were twice those of 2002 (3.7 and $1.9 \mathrm{mg} \mathrm{L}^{-1}$, respectively).

\section{Ammonium Nitrogen BUdget}

The ammonium nitrogen mass balance for both years, 2001 and 2002, could not be accurately determined as 
Table 4. Input and output average nitrogen and chloride concentrations to the study canal section during the 2002 flow period. Given ranges are with a $95 \%$ confidence interval: average \pm 1.96 (SD).

\begin{tabular}{|c|c|c|c|c|c|}
\hline Input/Output & $\begin{array}{l}\text { Ammonium } \\
\left(\mathrm{mg} \mathrm{L}^{-1}\right)\end{array}$ & $\begin{array}{c}\text { Nitrate-N } \\
\left(\mathrm{mg} \mathrm{L}^{-1}\right)\end{array}$ & $\begin{array}{l}\text { Organic-N } \\
\left(\mathrm{mg} \mathrm{L}^{-1}\right)\end{array}$ & $\begin{array}{l}\text { Total N } \\
\left(\mathrm{mg} \mathrm{L}^{-1}\right)\end{array}$ & $\begin{array}{l}\text { Chloride } \\
\left(\mathrm{mg} \mathrm{L}^{-1}\right)\end{array}$ \\
\hline Inflow at $\mathrm{S} 0^{[\mathrm{a}]}$ & 0.08 & 2.6 & 1.8 & 4.4 & 10.6 \\
\hline Throughfall[b] & $0.9 \pm 1.8$ & $0.5 \pm 0.6$ & $2.0 \pm 3.5$ & $3.4 \pm 4.9$ & $1.9 \pm 1.8$ \\
\hline Flow to/from fields ${ }^{[b]}$ & $0.2 \pm 0.4$ & $1.7 \pm 3.3$ & $1.5 \pm 1.4$ & $3.4 \pm 4.3$ & $14.5 \pm 14.3$ \\
\hline Litterfall & -- & -- & -- & -- & -- \\
\hline Outflow at S3[a] & 0.08 & 2.8 & 1.7 & 4.5 & 10.3 \\
\hline
\end{tabular}

[a] Concentrations are volume-weighted proportional averages for the flow period.

[b] Concentrations are averages of measured concentrations of samples taken during the flow period.

concentrations (reported from 0.001 to $0.1 \mathrm{mg} \mathrm{L}^{-1}$ ) were at or below the detection level of the analysis. Concentrations correlated more to lab batch than to sample date or location. It was assumed that the mass of ammonium input approximated that being discharged. Low ammonium concentrations are typical in drainage networks of coastal plain forested watersheds and indicate that the nitrification rate approximates the mineralization rate.

\section{Nitrate Nitrogen BUdGET}

The 2001 nitrate nitrogen mass balance indicated a surplus of only $2.8 \pm 32 \mathrm{~kg}\left(5 \mathrm{mg} \mathrm{m}^{-2} \mathrm{~d}^{-1}\right.$, fig. 11 ), or $1.3 \%$ (table 1 ). The major nitrate-N source in the study reach was inflow at S0, comprising $234 \mathrm{~kg}\left(451 \mathrm{mg} \mathrm{m}^{-2} \mathrm{~d}^{-1}\right)$, or $99.7 \%$ of the total net input. Throughfall input was minor $\left(0.6 \mathrm{~kg}\left(1 \mathrm{mg} \mathrm{m}^{-2}\right.\right.$ $\left.\mathrm{d}^{-1}\right)$, or $0.3 \%$ ). Net groundwater exchange produced a net loss of $19.4 \mathrm{~kg}\left(37 \mathrm{mg} \mathrm{m}^{-2} \mathrm{~d}^{-1}\right)$ nitrate-N during 2001. Daily nitrate-N loads for 2001 are shown in figure 13 . The nitrate$\mathrm{N}$ load associated with the $204 \mathrm{~m}^{3}$ of unaccounted-for flow in 2001 would equal $0.2 \mathrm{~kg}$, and if added to the total nitrate- $\mathrm{N}$ budget would result in a total surplus of $3.0 \mathrm{~kg}$ at the outlet. The surplus in the 2001 nitrate- $\mathrm{N}$ budget was most likely due to the variability in the groundwater and throughfall concentrations $\left( \pm 1.8\right.$ and $\pm 0.6 \mathrm{mg} \mathrm{L}^{-1}$, respectively; table 3). The $3.0 \mathrm{~kg}$ surplus was within the total variability of the inputs and outputs, $\pm 32.8 \mathrm{~kg}$, and was not considered significant. The close balance during 2001 was probably due to nitrification and denitrification occurring at similar rates within the reach, resulting in neither a net gain nor loss of nitrate. Nitrate-N concentrations were similar at the inflow S0, the outflow S3, and in groundwater (fig. 14).

During the 2002 flow period, there was a $22.2 \pm 13.8 \mathrm{~kg}$ (30 mg m $\mathrm{m}^{-2} \mathrm{~d}^{-1}$, fig. 12 ), or $2.4 \%$ nitrate-N surplus at the outlet (table 2). The inflow at S0 was the main source $(894 \mathrm{~kg}$ (1179 $\left.\mathrm{mg} \mathrm{m}^{-2} \mathrm{~d}^{-1}\right)$, or $99.1 \%$ ), while throughfall and groundwater were minor inputs $\left(0.6 \mathrm{~kg}\left(1 \mathrm{mg} \mathrm{m}^{-2} \mathrm{~d}^{-1}\right)\right.$ or $0.1 \%$, and $7.2 \mathrm{~kg}\left(9 \mathrm{mg} \mathrm{m}^{-2} \mathrm{~d}^{-1}\right)$ or $0.8 \%$, respectively). Daily nitrate-N loads for 2002 are shown in figure 15 . The nitrate$\mathrm{N}$ associated with the $8,280 \mathrm{~m}^{3}$ of unaccounted-for flow amounts to $21.5 \mathrm{~kg}$. This in addition to the $22.2 \mathrm{~kg}$ surplus in the nitrate- $\mathrm{N}$ budget resulted in a total combined surplus of $43.7 \mathrm{~kg}$ of nitrate- $\mathrm{N}$ at the outlet in 2002 . This surplus nitrate- $\mathrm{N}$ could not be accounted for by the groundwater and throughfall concentration variability $( \pm 3.3$ and $\pm 0.6 \mathrm{mg}$ $\mathrm{L}^{-1}$, respectively; table 4 ), which resulted in a nitrate-N load variability of $\pm 13.7 \mathrm{~kg}$. The total variability of inflows and outflows $(13.8 \mathrm{~kg})$ includes the nitrate surplus and indicates an unmeasured source in the system. The most likely source was mineralization-nitrification of organic- $\mathrm{N}$ in excess of denitrification. The difference in the nitrate nitrogen accumulation between 2001 and 2002 was most likely due to the combination of higher average flow velocity $\left(0.05 \mathrm{~m} \mathrm{~s}^{-1}\right.$ in 2001 and $0.09 \mathrm{~m} \mathrm{~s}^{-1}$ in 2002) and higher average organic nitrogen concentrations $\left(1.5 \mathrm{mg} \mathrm{L}^{-1}\right.$ in 2001 and $1.8 \mathrm{mg} \mathrm{L}^{-1}$ in 2002). The higher flow velocity in 2002 shortened residence time for organic and nitrate nitrogen in the reach, providing less opportunity for sediment exchange. Mineralization and nitrification occur primarily in the upper sediments, while denitrification occurs primarily in the deeper sediments (Hynes, 1983). The increased organic nitrogen loads could mean that more material was transported into the upper sediments, mineralized, and nitrified. The resultant nitrate could move into surface water or deeper into the sediment and be denitrified. The increased nitrate concentrations of 2002 would be offset by the combination of higher nitrate concentration in the upper sediment (reducing the concentration gradient within the upper sediments) due to increased mineralization and nitrification and the longer travel distance to the denitrification zone in the deeper sediments. The net result of this would be an increase in nitrate in the water column.

Groundwater nitrate-N concentrations were similar to the inflow and outflow in 2002 (fig. 16). During high flow in 2002, the concentration of these three sources was approximately twice that of 2001, while base flow and precipitation concentrations were similar in both years. A possible explanation for the higher nitrate-N concentrations during high discharge was dry antecedent conditions in 2002. Rainfall for the last six months of 2001 was only $319 \mathrm{~mm}$, compared to $630 \mathrm{~mm}$ for the last six months of 2000 (Diggs, 2004). Nitrate-N likely accumulated in the soil due to mineralization and was not flushed during the dry sixmonth period before the 2002 flow period. Some nitrate-N in the soil was likely flushed during the wetter six-month period before the 2001 flow period.

\section{Organic Nitrogen Budget}

The organic- $\mathrm{N}$ mass balance indicated a large decrease along the reach of $28.6 \pm 27.2 \mathrm{~kg}\left(56 \mathrm{mg} \mathrm{m}^{-2} \mathrm{~d}^{-1}\right.$, fig. 11) or $10.1 \%$ in 2001 (table 1). The major input of organic- $\mathrm{N}$ to the canal section was upstream inflow $\left(337 \mathrm{~kg}\left(650 \mathrm{mg} \mathrm{m}^{-2} \mathrm{~d}^{-1}\right)\right.$ or $97.2 \%)$, while throughfall and litterfall were minor $(1.0 \mathrm{~kg}$ $\left(2 \mathrm{mg} \mathrm{m}^{-2} \mathrm{~d}^{-1}\right)$ or $0.3 \%$, and $8.5 \mathrm{~kg}\left(16 \mathrm{mg} \mathrm{m}^{-2} \mathrm{~d}^{-1}\right)$ or $2.5 \%$, respectively). Groundwater exchange resulted in a net loss of $33.9 \mathrm{~kg}\left(65 \mathrm{mg} \mathrm{m}^{-2} \mathrm{~d}^{-1}\right)$ of organic-N from the reach. Daily organic-N loads for 2001 are shown in figure 17. A small portion of the 2001 organic- $N$ deficit $(0.3 \mathrm{~kg})$ can be attributed to the missing $204 \mathrm{~m}^{3}$ flow in the water budget. This amount was subtracted because it resulted in an overestimation of organic-N input, leaving $28.3 \mathrm{~kg}$ unaccounted for. This $28.3 \mathrm{~kg}$ can be almost completely accounted for by the concentration variability in ground- 


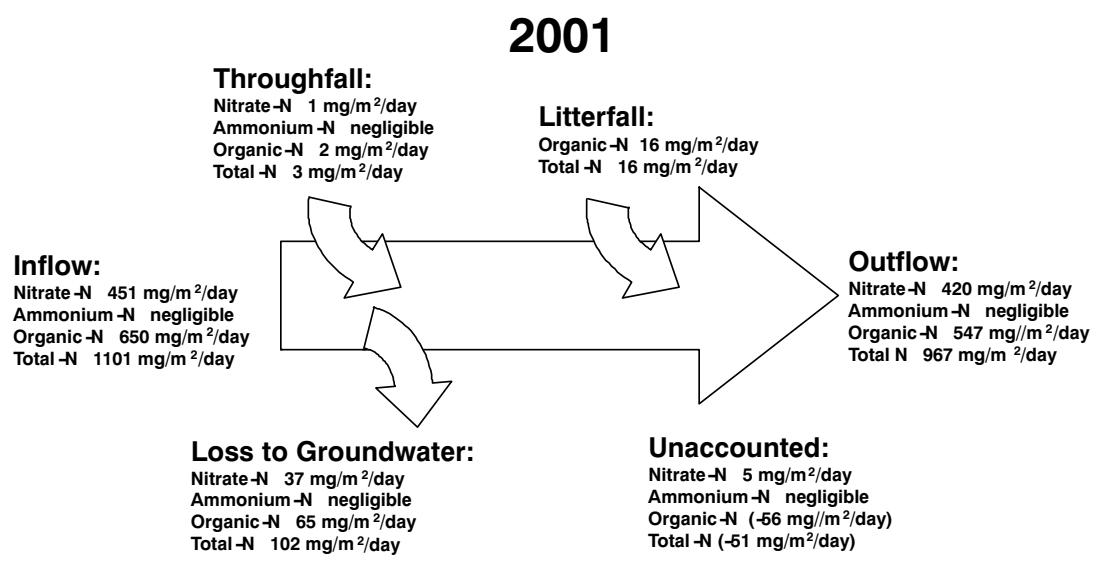

Figure 11. Nitrogen budget (per square meter of sediment surface per day) for the flow period 14 February to 1 May in 2001.

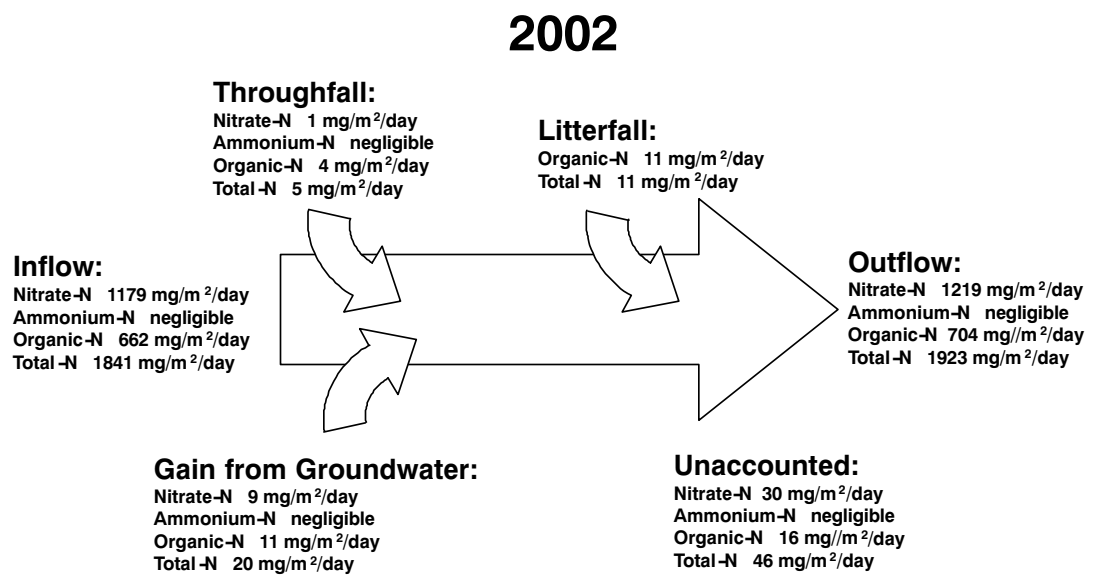

Figure 12. Nitrogen budget (per square meter of sediment surface per day) for the flow period 22 January to 14 May in 2002.

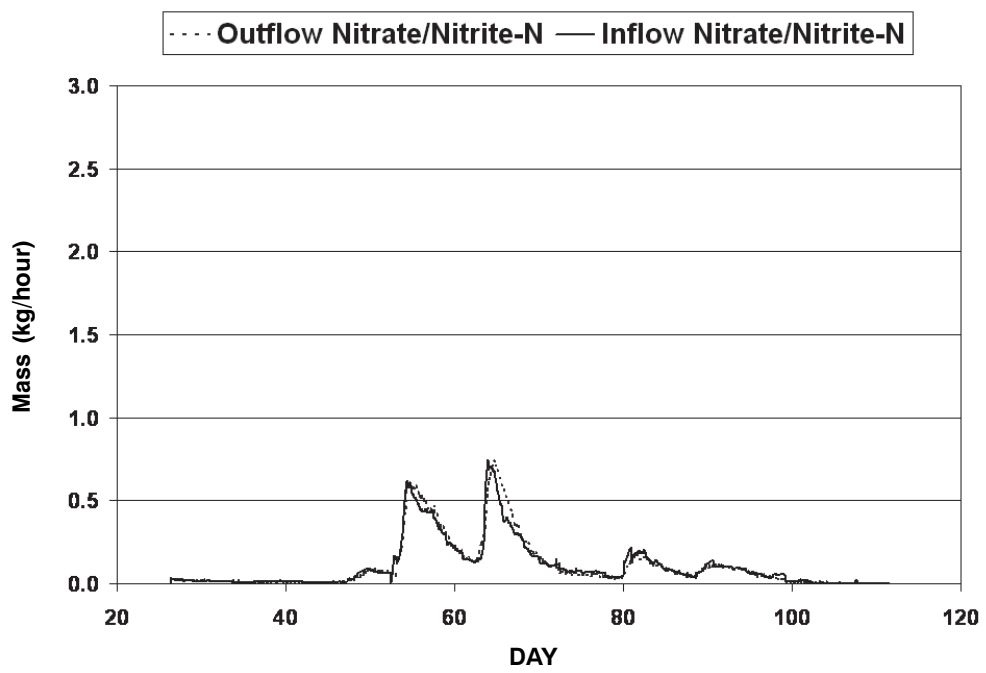

Figure 13. Daily nitrate-N outflow and sum of inflows rates for the flow period 14 February to 1 May in 2001.

water, throughfall, litterfall, inflow, and outflow. The organic- $\mathrm{N}$ variability in the sum of inputs and outputs resulted in a total load variability of $\pm 27.2 \mathrm{~kg}$. This indicated that the organic- $\mathrm{N}$ input rate approximated mineralization and nitrification during 2001. Groundwater concentrations of organic-N were similar to the inflow at S0 and outflow at S3 (fig. 18).
In 2002, the organic-N mass balance indicated a surplus at the outlet (13.1 $\pm 19.0 \mathrm{~kg}\left(16 \mathrm{mg} \mathrm{m}^{-2} \mathrm{~d}^{-1}\right.$, fig. 12$)$ or $\left.2.5 \%\right)$. The major input was inflow at S0, with $502 \mathrm{~kg}\left(662 \mathrm{mg} \mathrm{m}^{-2}\right.$ $\mathrm{d}^{-1}$ ) or $96.3 \%$ of the total input (table 2). Throughfall, groundwater, and litterfall were minor $\left(2.7 \mathrm{~kg}\left(4 \mathrm{mg} \mathrm{m}^{-2} \mathrm{~d}^{-1}\right)\right.$ or $0.5 \%, 8.1 \mathrm{~kg}\left(11 \mathrm{mg} \mathrm{m}^{-2} \mathrm{~d}^{-1}\right)$ or $1.6 \%$, and $8.1 \mathrm{~kg}(11 \mathrm{mg}$ $\mathrm{m}^{-2} \mathrm{~d}^{-1}$ ) or $1.6 \%$, respectively). In 2002 , an additional 


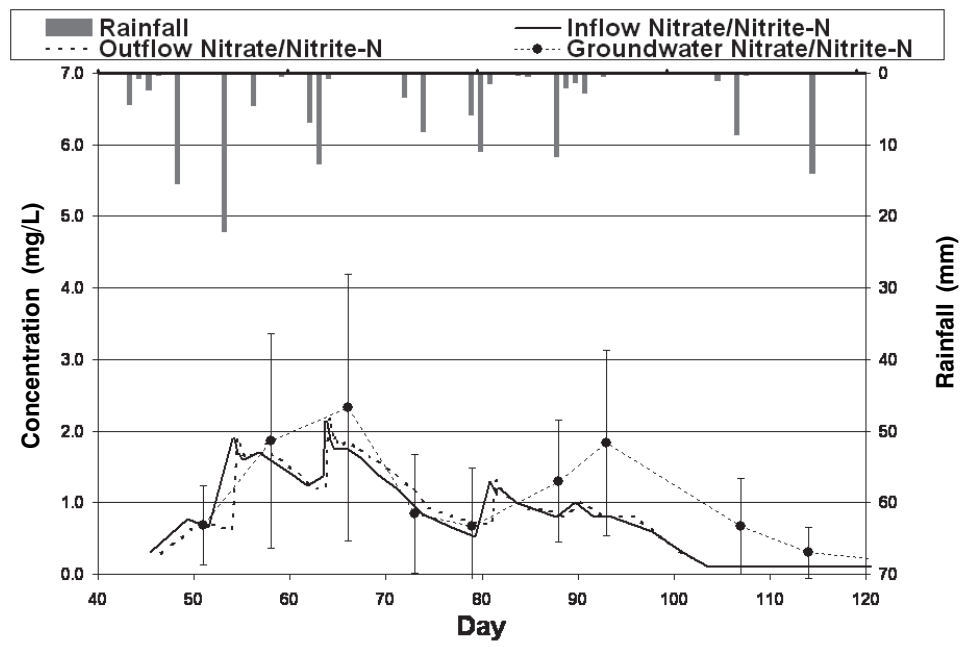

Figure 14. 2001 Nitrate-N concentrations for inflow at S0, outflow at S3, and in groundwater (groundwater samples have a $95 \%$ confidence interval shown).

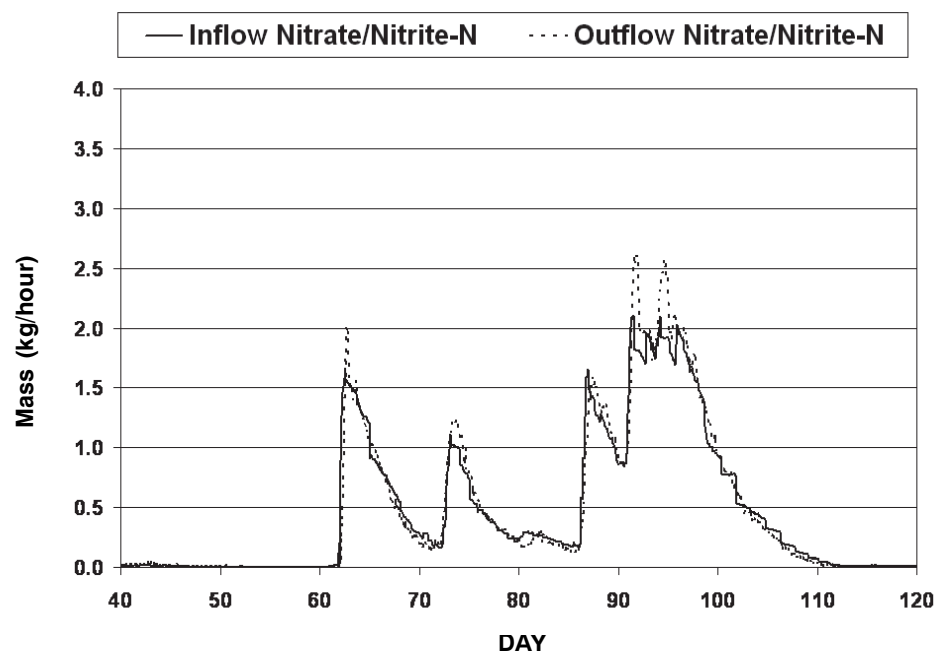

Figure 15. Daily nitrate-N outflow and sum of inflows rates for the flow period 22 January to 14 May in 2002.

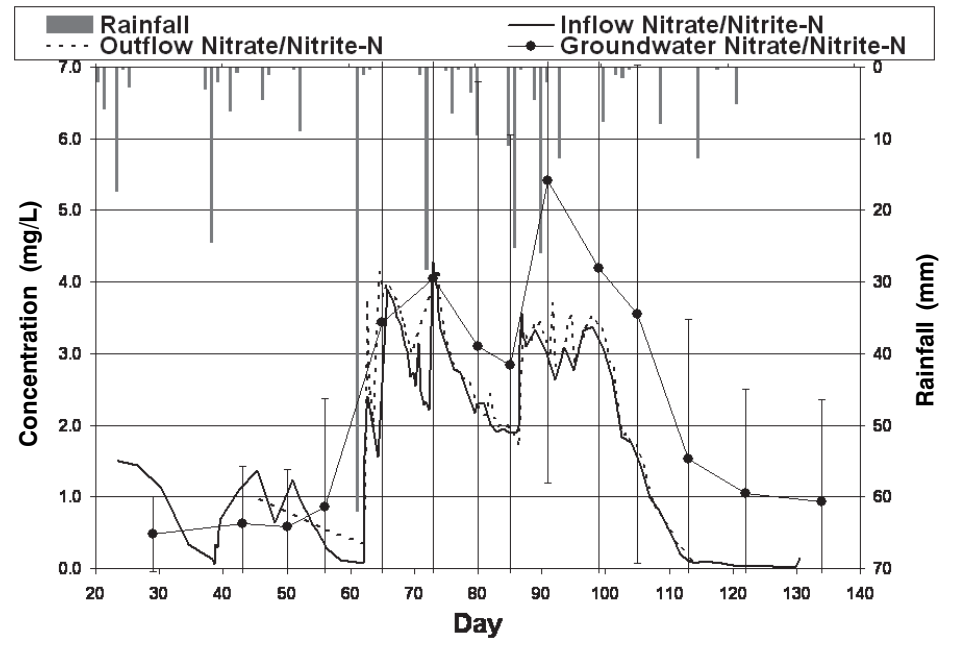

Figure 16. 2002 Nitrate-N concentrations for inflow at S0, outflow at S3, and in groundwater (groundwater samples have a $95 \%$ confidence interval shown). 


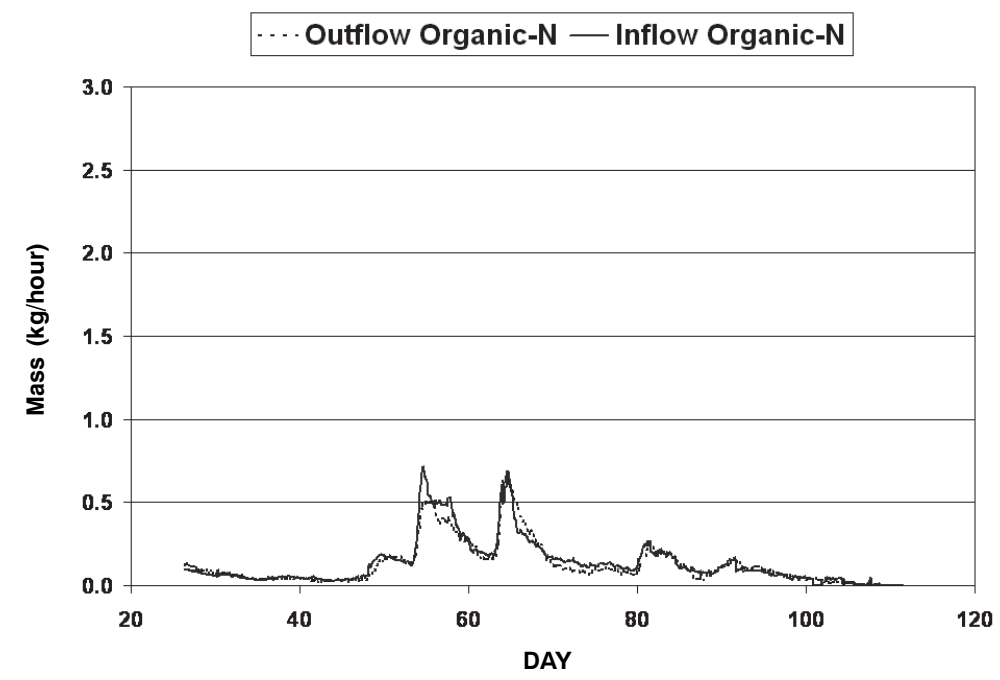

Figure 17. Daily organic-N outflow and sum of inflows rates for the flow period 14 February to 1 May in 2001.

$14.9 \mathrm{~kg}$ of organic- $\mathrm{N}$ was attributed to the $8,280 \mathrm{~m}^{3}$ shortfall in the water budget, producing a total $28.0 \mathrm{~kg}$ surplus in the budget. As with the nitrate- $\mathrm{N}$ budget in 2002, this excess of organic- $\mathrm{N}$ cannot be accounted for by concentration variability in the groundwater and throughfall components ( \pm 1.4 and $\pm 3.5 \mathrm{mg} \mathrm{L} \mathrm{L}^{-1}$, respectively; table 4 ) or by variability in litterfall, inflow, or outflow, which resulted in a load variability of $\pm 19.0 \mathrm{~kg}$. This left a total of $9.0 \mathrm{~kg}$ excess organic- $\mathrm{N}$ at the outlet, indicating an unmeasured source of organic-N. This excess organic-N may have been due to higher losses of organic- $\mathrm{N}$ from the benthic organic layer during high flow in 2002. This area needs further investigation. Daily organic-N loads are shown in figure 19. Groundwater concentrations of organic-N were lower than the inflow and outflow until the first large rainfall (day 62), after which all three concentrations became similar (fig. 20).

The assumption that the amount of nitrogen entering the canal through litterfall was roughly equal to the amount of nitrogen entering the canal from the organic layer at the bottom of the canal appears valid. In a separate study, Appelboom (2004) found that the amount of ammonium nitrogen entering the water column via mineralization within this layer was $7.6 \pm 1.8 \mathrm{~kg}$ in 2001 and $7.3 \pm 1.8 \mathrm{~kg}$ in 2002 , compared to litterfall mass input of $8.5 \pm 3.5 \mathrm{~kg}$ in 2001 and $8.1 \pm 2.5 \mathrm{~kg}$ in 2002 .

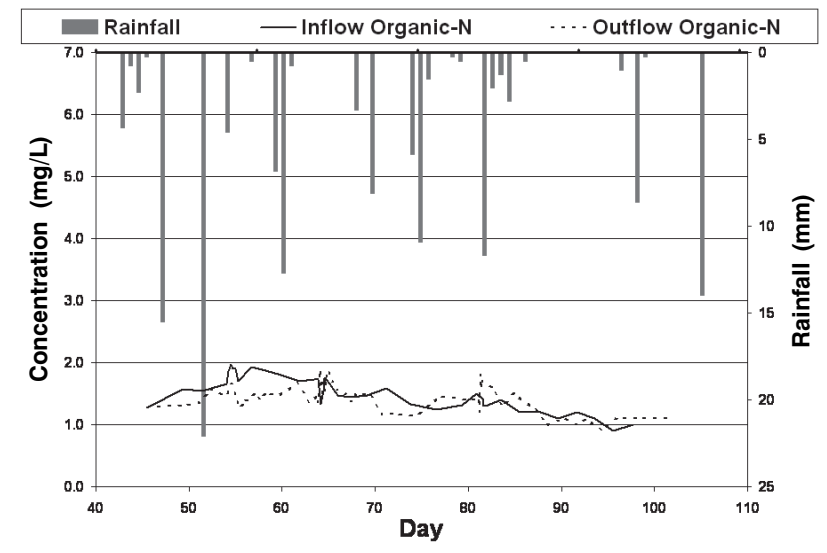

Figure 18. 2001 organic-N concentrations for inflow at S0, outflow at S3, and in groundwater (groundwater samples have a $95 \%$ confidence interval shown).

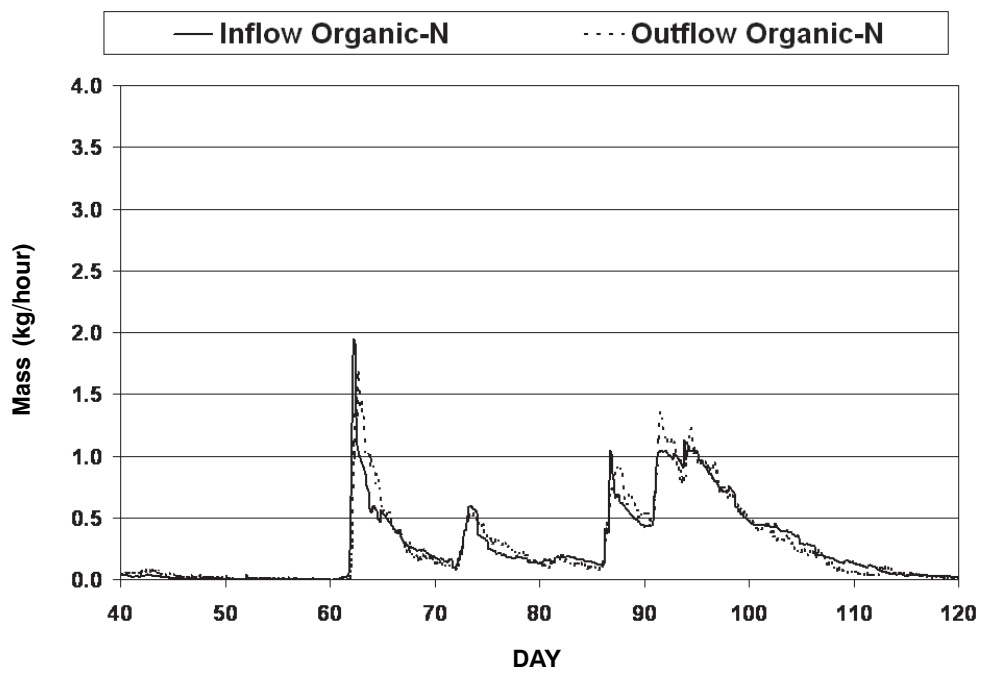

Figure 19. Daily organic-N outflow and sum of inflows rates for the flow period 22 January to 14 May in 2002. 


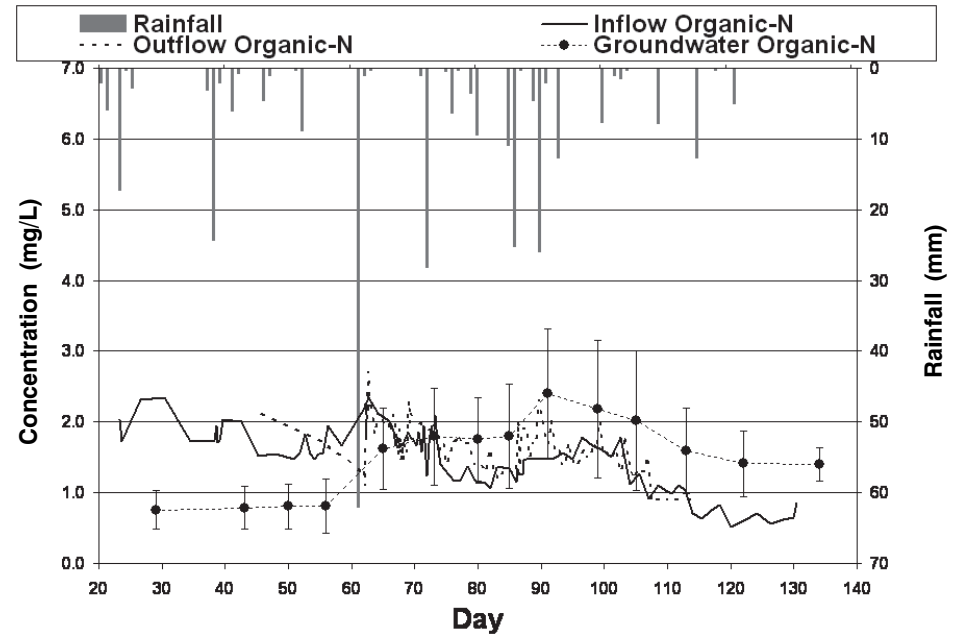

Figure 20. 2002 Organic-N concentrations for inflow at S0, outflow at S3, and in groundwater (groundwater samples have a 95\% confidence interval shown).

\section{Total Nitrogen BUdget}

The total- $\mathrm{N}$ mass balance indicated an overall reach decrease of $25.8 \pm 42.0 \mathrm{~kg}(5.1 \%)$ in 2001 (table 1). Upstream inflow was the main input, $571 \mathrm{~kg}(98.2 \%)$, while throughfall and litterfall were minor at $1.6 \mathrm{~kg}(0.3 \%)$ and $8.5 \mathrm{~kg}(1.5 \%)$, respectively. In 2001, groundwater exchange resulted in a net loss of $53.3 \mathrm{~kg}$ of total-N. Only a small portion of the total-N deficit $(0.6 \mathrm{~kg})$ can be attributed to the $204 \mathrm{~m}^{3}$ of unaccounted-for flow. This amount is subtracted because it resulted in an overestimation of the total-N inputs, leaving $25.2 \mathrm{~kg}$ of total-N deficit, which was within the total variability of the inputs and outputs, $\pm 42.0 \mathrm{~kg}$, and could not be considered significant. This balance indicated that the rates of organic nitrogen input, mineralization, nitrification, and denitrification occurred at similar rates during 2001. Daily total nitrogen loads are shown in figure 21 .

During the 2002 flow season, the mass balance of total-N indicated a surplus of $35.3 \pm 23.6 \mathrm{~kg}(2.4 \%)$ at $\mathrm{S} 3$ (table 2). Upstream inflow was the main input, $1396 \mathrm{~kg}(98.0 \%)$, while throughfall, groundwater, and litterfall were minor at $3.3 \mathrm{~kg}$ $(0.2 \%), 15.3 \mathrm{~kg}(1.1 \%)$, and $8.1 \mathrm{~kg}(0.6 \%)$, respectively. With the addition of $36.8 \mathrm{~kg}$ total- $\mathrm{N}$ input attributed to the
$8,280 \mathrm{~m}^{3}$ shortfall in the water budget, a surplus of $72.1 \mathrm{~kg}$ of total-N was unaccounted for. This surplus exceeds groundwater and throughfall concentration variability $( \pm 4.3$ and $\pm 4.9 \mathrm{mg} \mathrm{L}^{-1}$, respectively; table 4 ), and the variability of litterfall inputs, inflow, and outflow. The total variability of the inputs and outputs resulted in a load variability of $\pm 23.6 \mathrm{~kg}$, only $33 \%$ of the $72.1 \mathrm{~kg}$ surplus. The increase in total- $\mathrm{N}$, the combined increase of nitrate- $\mathrm{N}$ and organic- $\mathrm{N}$, indicated an unmeasured nitrogen source, possibly from the organic layer lining the bottom of the channel. Daily total nitrogen loads are shown in figure 22.

\section{COMPARISON OF Storm Flow ANd BASE Flow Nitrogen CONCENTRATIONS}

Nitrate-N concentrations during flow events increased in both the groundwater and canal water samples as compared to base flow (figs. 15 and 17). This was due to soil mineralization-nitrification with accumulation during dry periods, and high nitrate- $\mathrm{N}$ mobility. Combined with the increased flow, large spikes in daily nitrate-N loads occurred during rainfall events (figs. 14 and 16).

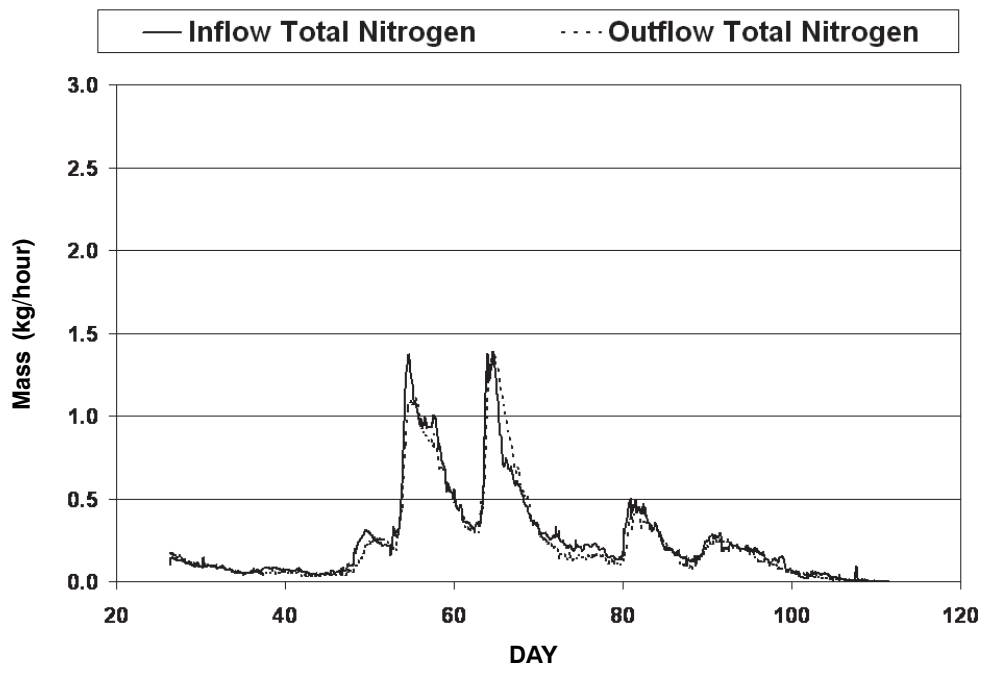

Figure 21. Daily total nitrogen outflow and sum of inflows rates for the flow period 14 February to 1 May in 2001. 


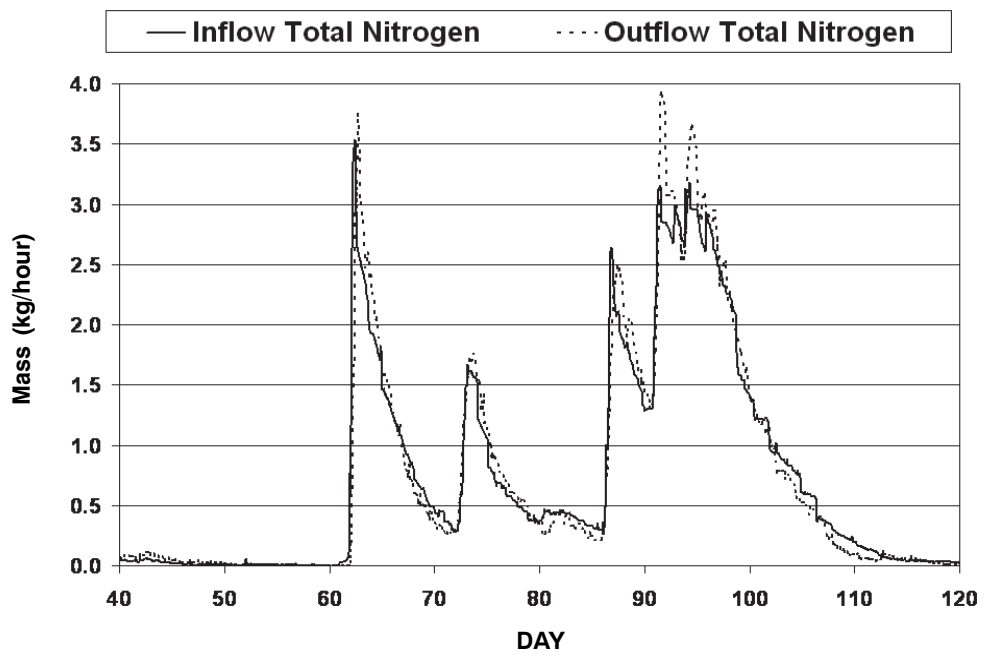

Figure 22. Daily total nitrogen outflow and sum of inflows rates for the flow period 22 January to 14 May in 2002.

The groundwater and canal water organic- $\mathrm{N}$ concentrations in 2001 declined slowly from a high of around $2.0 \mathrm{mg} \mathrm{L}^{-1}$ to just below $1.0 \mathrm{mg} \mathrm{L}^{-1}$ in the canal water and from a high of around $2.4 \mathrm{mg} \mathrm{L}^{-1}$ to just below $1.0 \mathrm{mg} \mathrm{L}^{-1}$ in the groundwater (fig. 18). After flow stopped at around day 100, the organic-N concentration in the canal water started increasing as the canal water became stagnant with continued litterfall input. In 2002, the canal water organic- $\mathrm{N}$ concentrations also decreased slowly (fig. 20). The groundwater concentration increased until around day 90, after which it declined slowly. The decrease in organic$\mathrm{N}$ concentrations of the canal water in both years is likely due to a large amount of organic material built up from litterfall and lateral movement prior to the initiation of flow. As flow started and continued, the available leachate from particulate organic material decreased in dissolved organic- $\mathrm{N}$ concentration over time. Enhanced rainfall between day 60 and day 95 during 2002 may have facilitated organic material transport through leachate or particulates through preferential flow channels, increasing organic- $\mathrm{N}$ concentrations in the groundwater during that time. Organic-N loads during both years showed large, proportional increases related to discharge and rainfall events compared to base flow.

\section{COMPARISON To OTHER STUdiES}

This study is difficult to compare to others that did not measure the full range of hydrologic and allochthonous inputs or the full range of nitrogen species.
Concentrations of ammonium-N, nitrate-N, and organic$\mathrm{N}$ observed in throughfall were higher relative to areas of less-intense animal production (Waquoit Bay, Mass., and the Blue Mountains of Jamaica; table 5), but lower than areas of higher animal production and/or industrial emissions such as Flanders, Belgium; Gisburn, U.K.; and Wekeromsche Zand, The Netherlands (table 5). The coastal plain of North Carolina has high hog production but comparatively smaller nitrogen emissions to the atmosphere than the hog, poultry, and other animal production in Western Europe (table 5) and has few industrial emissions. Additionally, the broad-leaf riparian vegetation overhanging the canal section in this study has less surface area than pine, thus holding less dry deposition until rainfall events. This vegetative aspect can be seen by comparing the silver birch and Corsican pine in Flanders, Belgium. The Corsican pine had much higher nitrogen concentrations than the silver birch (table 5). All locations showed increased nitrogen concentrations by passing through the canopy as compared to the rainfall concentrations (Appelboom, 2004).

Groundwater samples from all the studies listed in table 6 had low ammonium-N concentrations $\left(<0.4 \mathrm{mg} \mathrm{L}^{-1}\right)$ with the exception of Flanders, Belgium, under Corsican pine, which had an ammonium-N concentration of $0.91 \mathrm{mg} \mathrm{L}^{-1}$. These low ammonium levels are typical, as nitrification readily converts the ammonium to nitrate if groundwater is aerobic. If groundwater is anaerobic, then ammonium will

Table 5. Volume-weighted mean solution nitrogen concentrations of throughfall from different locations.

\begin{tabular}{|c|c|c|c|c|c|c|}
\hline Location & Stand Type & $\begin{array}{l}\mathrm{NH}_{4}-\mathrm{N} \\
\left(\mathrm{mg} \mathrm{L}^{-1}\right)\end{array}$ & $\begin{array}{l}\mathrm{NO}_{3}-\mathrm{N} \\
\left(\mathrm{mg} \mathrm{L}^{-1}\right)\end{array}$ & $\begin{array}{l}\text { Organic-N } \\
\left(\mathrm{mg} \mathrm{L}^{-1}\right)\end{array}$ & $\begin{array}{l}\text { Total N } \\
\left(\mathrm{mg} \mathrm{L}^{-1}\right)\end{array}$ & Source \\
\hline Waquoit Bay, Massachusetts & Mixed oaks & 0.13 & 0.42 & 0.44 & 0.99 & Seely et al., 1988 \\
\hline Watershed 10 , Oregon & Douglas fir & -- & -- & -- & 0.13 & Triska et al., 1984 \\
\hline Flanders, Belgium & Silver birch & 2.65 & 0.77 & -- & -- & De Schrijver et al., 2000 \\
\hline Flanders, Belgium & Corsican pine & 12.74 & 2.38 & -- & -- & De Schrijver et al., 2000 \\
\hline Gisburn, U.K. & Scots pine & 3.6 & 6.2 & -- & -- & Robertson et al., 2000 \\
\hline Wekeromsche Zand, The Netherlands & Scots pine & 8.65 & 2.10 & -- & -- & Berg and Verhoef, 1998 \\
\hline $\begin{array}{l}\text { Bear Brook, Hubbard Brook Experimental } \\
\text { Forest, New Hampshire }\end{array}$ & Mixed hardwood & -- & -- & -- & 2.68 & Meyer et al., 1981 \\
\hline Manaus, Brazil & Eschweilera & -- & -- & -- & 0.71 & Schroth et al., 2001 \\
\hline Manaus, Brazil & Oenocarpus & -- & -- & -- & 0.60 & Schroth et al., 2001 \\
\hline Blue Mountains, Jamaica & Mixed forest & 0.04 & 0.02 & 0.03 & 0.09 & McDonald and Healey, 2000 \\
\hline Plymouth, North Carolina & Mixed forest & 0.82 & 0.62 & 1.84 & 3.28 & This study \\
\hline
\end{tabular}


Table 6. Average nitrogen concentrations of groundwater from different locations.

\begin{tabular}{|c|c|c|c|c|c|c|}
\hline Location & Stand Type & $\begin{array}{c}\mathrm{NH}_{4}-\mathrm{N} \\
\left(\mathrm{mg} \mathrm{L}^{-1}\right)\end{array}$ & $\begin{array}{l}\mathrm{NO}_{3}-\mathrm{N} \\
\left(\mathrm{mg} \mathrm{L}^{-1}\right)\end{array}$ & $\begin{array}{l}\text { Organic-N } \\
\left(\mathrm{mg} \mathrm{L}^{-1}\right)\end{array}$ & $\begin{array}{c}\text { Total N } \\
\left(\mathrm{mg} \mathrm{L}^{-1}\right)\end{array}$ & Source \\
\hline Waquoit Bay, Massachusetts & Mixed oaks & 0.03 & 0.01 & 0.13 & 0.17 & Seely et al., 1988 \\
\hline Flanders, Belgium & Silver birch & 0.37 & 6.63 & -- & -- & De Schrijver et al., 2000 \\
\hline Flanders, Belgium & Corsican pine & 0.91 & 15.54 & -- & -- & De Schrijver et al., 2000 \\
\hline Gisburn, U.K. & Scots pine & 0.00 & 1.3 & -- & -- & Robertson et al., 2000 \\
\hline Watershed 10 , Oregon & Douglas fir & 0.00 & $\begin{array}{l}0.38 \mathrm{~kg} \text { to } \\
\text { stream }\end{array}$ & $\begin{array}{l}8.49 \mathrm{~kg} \text { to } \\
\text { stream }\end{array}$ & $\begin{array}{l}8.87 \mathrm{~kg} \text { to } \\
\text { stream }\end{array}$ & Triska et al. 1984 \\
\hline Lye Brook Wilderness, Vermont & Mixed forest & 0.34 & 0.29 & 0.50 & 1.13 & Campbell et al., 2000 \\
\hline Coastal Plain, South Carolina & Loblolly pine & 0.06 & 0.20 & -- & -- & Wells et al., 1985 \\
\hline Tennessee & Yellow poplar & - & 0.4 & -- & -- & Johnson and Todd, 1988 \\
\hline Oak Ridge, Tennessee & Sycamore & - & 0.1 & -- & -- & Van Miegroet et al., 1994 \\
\hline Central Sweden & Norway spruce & 0.23 & 0.11 & -- & -- & Nohrstedt, 1992 \\
\hline Klosterhede, Denmark & Norway spruce & 0.01 & 0.1 & -- & -- & Gunderson and Rasmussen, 1995 \\
\hline $\begin{array}{l}\text { Hubbard Brook Experimental } \\
\text { Forest, New Hampshire }\end{array}$ & Mixed hardwood & 0.02 & 0.25 & 0.04 & 0.31 & Meyer et al., 1981 \\
\hline Plymouth North Carolina & Mixed forest & 0.62 & 1.20 & 1.67 & 3.49 & This study \\
\hline
\end{tabular}

Table 7. Average amount of organic nitrogen in litterfall from different locations.

\begin{tabular}{|c|c|c|c|c|}
\hline Location & Stand Type & $\begin{array}{l}\text { Litterfall Mass } \\
\left(\mathrm{kg} \mathrm{ha}^{-1} \text { year }^{-1}\right)\end{array}$ & $\begin{array}{l}\text { Total N } \\
\left(\mathrm{mg} \mathrm{g}^{-1}\right)\end{array}$ & Source \\
\hline Blue Mountains, Jamaica & Mixed forest & 9318 & 8.33 & McDonald and Healey, 2000 \\
\hline Black Forest, Germany & Norway spruce & -- & 17.1 & Lorenz, et al., 2000 \\
\hline Black Sturgeon Forest, Ontario Canada & Black spruce & -- & 10.1 & Lorenz, et al., 2000 \\
\hline Wekeromsche Zand, Netherlands & Scots pine & 3650 & 9.0 & Berg and Verhoef, 1998 \\
\hline Laurel Creek, Ontario, Canada & Mixed hardwood & 3238 & 7.52 & Oelbermann and Gordon, 2000 \\
\hline South Carolina & Mixed hardwood (stream) & 5947 & -- & Muzika et al., 1987 \\
\hline South Carolina & Mixed hardwood (riverine) & 5517 & -- & Muzika et al., 1987 \\
\hline $\begin{array}{l}\text { Hubbard Brook Experimental Forest, } \\
\text { New Hampshire }\end{array}$ & Mixed hardwood & -- & $\begin{array}{l}49.0 \mathrm{~kg} \mathrm{year}^{-1} \\
\text { to stream }\end{array}$ & Meyer et al., 1981 \\
\hline $\begin{array}{l}\text { Hubbard Brook Experimental Forest, } \\
\text { New Hampshire }\end{array}$ & Mixed hardwood & 5702 & 9.5 & Gosz et al., 1972 \\
\hline Watershed 10 , Oregon & Douglas fir & 1931 & 5.4 & Triska et al., 1984 \\
\hline Plymouth, North Carolina & Mixed forest & 4891 & 12.1 & This study \\
\hline
\end{tabular}

Table 8. Average volume weighted nitrogen concentrations of stream water from different locations.

\begin{tabular}{|c|c|c|c|c|c|c|}
\hline Location & Stand Type & $\begin{array}{l}\mathrm{NH}_{4}-\mathrm{N} \\
\left(\mathrm{mg} \mathrm{L}^{-1}\right)\end{array}$ & $\begin{array}{l}\mathrm{NO}_{3}-\mathrm{N} \\
\left(\mathrm{mg} \mathrm{L}^{-1}\right)\end{array}$ & $\begin{array}{l}\text { Organic-N } \\
\left(\mathrm{mg} \mathrm{L}^{-1}\right)\end{array}$ & $\begin{array}{l}\text { Total N } \\
\left(\mathrm{mg} \mathrm{L}^{-1}\right)\end{array}$ & Source \\
\hline Aroostook River Basin, Maine & Mixed forest & 0.08 & 0.20 & -- & -- & Cronan et al., 1999 \\
\hline Beaufort, North Carolina & $\begin{array}{l}\text { Loblolly pine } \\
\text { plantation }\end{array}$ & 0.12 & 0.02 & 1.08 & 1.22 & Lebo and Herrmann, 1998 \\
\hline Carteret County, North Carolina & $\begin{array}{l}\text { Loblolly pine } \\
\text { plantation }\end{array}$ & 0.08 & 0.93 & 1.26 & 2.27 & Amatya et al., 1998 \\
\hline Piedmont, North Carolina & Loblolly pine & 0.04 & 0.80 & 0.70 & 1.54 & Fromm and Herrmann, 1996 \\
\hline Coastal Plain, Florida & Slash pine & 0.1 & 0.1 & 0.9 & 1.1 & Fisher, 1981 \\
\hline Fernow, West Virginia & Mixed & 0.23 & 0.76 & -- & -- & Aubertin et al., 1973 \\
\hline Central Oregon & Douglas fir & 0.0 & 0.0 & 0.15 & 0.15 & Stay et al., 1979 \\
\hline Coastal Range, Washington & Douglas fir & 0.03 & 0.60 & 0.20 & 0.83 & Bisson et al., 1992 \\
\hline Central Sweden & Norway spruce & -- & 0.02 & 0.22 & -- & Ring and Nohrstedt, 1993 \\
\hline New Zealand & Radiata pine & 0.00 & 0.00 & 0.32 & 0.32 & Leonard, 1977 \\
\hline Watershed 10, Oregon & Douglas fir & -- & 330 g year $^{-1}$ & 0.50 & -- & Triska et al., 1984 \\
\hline $\begin{array}{l}\text { Hubbard Brook Experimental Forest, } \\
\text { New Hampshire }\end{array}$ & Mixed hardwood & 0.02 & 0.25 & 0.04 & -- & Meyer et al., 1981 \\
\hline Lye Brook Wilderness, Vermont & Mixed forest & 0.10 & 0.01 & 0.30 & 0.41 & Campbell et al., 2000 \\
\hline Plymouth, North Carolina & Mixed forest & 0.08 & 2.33 & 1.72 & 4.13 & This study[a] \\
\hline
\end{tabular}

[a] Concentrations at the upstream inflow of the study reach.

dominate. The higher ammonium-N concentration of the Flanders, Belgium, groundwater is likely linked directly to the high ammonium concentrations (12.74 $\mathrm{mg} \mathrm{L}^{-1}$, table 5) in the throughfall at that location. We would expect the same at Wekeromsche Zand, The Netherlands, if groundwater concentrations were reported for that site. The high nitrate-N groundwater concentrations found in the three sites (Flanders, (Belgium, and Gisburn, U.K.) reflect the high throughfall nitrate-N and ammonium-N. The drought condition allowed nitrates to build up, with subsequent release during rainfall events. In a water quality study of forested lands in eastern North Carolina, Chescheir et al. 
(2003) found that mean seasonal concentrations in drainage water from $75 \%$ of the sites studied were less than $0.6 \mathrm{mg} \mathrm{L}^{-1}$ for nitrate-N, $1.5 \mathrm{mg} \mathrm{L}^{-1}$ for organic-N, and $1.8 \mathrm{mg} \mathrm{L}^{-1}$ for total-N. Total-N and organic-N concentrations were highest from sites with organic soils, while nitrate-N concentrations were highly variable from organic soils, depending on conditions that promote mineralization-nitrification.

The organic nitrogen content of the litterfall/lateral movement material in this study was similar to the studies listed in table 7. Generally, the mixed hardwood stands had higher total litterfall/lateral movement mass than pine forests.

Average stream water ammonium-N concentrations in this study were similar to the studies listed in table 8, and all were very low. Average nitrate-N concentrations in the drainage water from the reach were higher than those of the other studies listed in table 8 . This is most likely due to a combination of the high organic content soils and the drought that occurred over the two-year period of this study. The average stream water organic- $\mathrm{N}$ concentrations from this study were higher than the other studies listed in table 8 , but were similar to the two other North Carolina coastal plain studies. This is again most likely due to the presence of highly organic soils.

\section{Conclusions}

It was possible to identify and quantify each of the hydrologic and nitrogen inputs and outputs to overall water and nitrogen budgets for a $1900 \mathrm{~m}$ reach during winter-spring flows. The major input and output of each were the inflow (S0) and outflow (S3). Due to the drought conditions, throughfall and groundwater inputs were minor. Groundwater contributions/losses were the most difficult to measure due to the high variability of the soil conductivities. Variability of groundwater contributions was responsible for most measurement errors in both the water and nitrogen budgets.

Accounting for approximately $98 \%$ of inputs and outputs, the inflow at S0 and outflow at S3 hydrographs and chemographs were very similar both daily and cumulatively. Most differences between the two could be accounted for by the groundwater, throughfall, and litterfall/lateral movement inputs to the reach and their associated variability. Inflow and outflow nitrogen concentrations were similar for each nitrogen species.

The nitrate- $\mathrm{N}$ and organic-N concentrations were similar for both the reach surface water and ground water during both years. Average concentrations for these two components were generally higher in groundwater than surface water, but the variability in groundwater concentration was large, over $100 \%$ at times. Higher-intensity sampling at each site coupled with more sampling sites would improve the estimation of the groundwater contributions to the overall budgets.

Most discharge and nitrogen moved through the reach during rainfall events, and load was proportional to the magnitude of the event. When events occurred, more nitrates were transported to the channel from the surrounding soil profile, where they had accumulated during dry periods. Higher velocities and increased water depth also decreased the potential for nitrogen removal through denitrification.
Nitrate-N concentrations increased dramatically during storm events, while organic-N concentrations were relatively unaffected.

The mass balance approach used here to determine the amount of nitrogen removed/retained was not reliable for this canal. Compared to the total nitrogen load, the calculated removed/retained nitrogen amount was small, less than the summed variabilities of the different inputs and outputs. The accuracy of a mass balance approach may be improved by more intense monitoring of groundwater inflows and outflows and by using a longer canal section. Mass balance experiments, however, are very expensive and time consuming. Other methods of estimating removal or retention rates such as in-stream chambers, background $\mathrm{N}^{15}$, and intact cores may be more practical.

\section{ACKNOWLEDGEMENTS}

This work was supported in part by USDA NRI (Contract 98-35102-6493), the EPA 319 Program (Project EW9024), and by Weyerhaeuser Company. The authors wish to acknowledge Eugene Boyce, Wilson Huntley, and Jay Frick for their assistance in this study and Joe Hughs, Joe Bergman, Jamie Nettles, and Cliff Tyson of Weyerhaeuser Company for their cooperation and contributions to this study.

\section{REFERENCES}

Amatya, D. M., J. W. Gilliam, R. W. Skaggs, M. E. Lebo, and R. G. Campbell. 1998. Effects of controlled drainage on forest water quality. J. Environ. Qual. 27(4): 923-935.

APHA. 1989. Standard Methods for the Examination of Water and Waste Water. 17th ed. 1989. Washington, D.C.: American Public Health Association, American Waterworks Association, and Water Pollution Control Federation.

Appelboom, T. W. 2004. Effects of in-stream processes on the fate of nitrogen and phosphorous in drainage canals of forested watersheds. PhD diss. Raleigh, N.C.: North Carolina State University.

Aubertin, G. M., D. W. Smith, and J. H. Partice. 1973. Quantity and quality of streamflow after urea fertilization on a forested watershed: First year results. In Proc. Forest Fertilization Symposium, 88-100. General Technical Report NE-3. Radnor, Pa.: USDA Forest Service.

Berg, M. P., and H. A. Verhoef. 1998. Ecological characteristics of a nitrogen-saturated coniferous forest in The Netherlands. Biol. Fertil. Soils 26(4): 258-267.

Binkley, D., H. Burnham, and H. L. Allen. 1999. Water quality impacts of forest fertilization with nitrogen and phosphorous. Forest Ecol. Mgmt. 121(3): 191-213.

Bisson, P. A., G. G. Ice, C. J. Perrin, and R. E. Bilby. 1992. Effects of forest fertilization on water quality and aquatic resources in the Douglas-fir region. In Forest Fertilization: Sustaining and Improving Nutrition and Growth of Western Forests, 179-193. Seattle, Wash.: University of Washington.

Boling, R. H., E. D. Goodman, J. A. Van Sickle, J. O. Zimmer, K. W. Cummins, R. C. Busch, and S. G. Fisher. 1981. Metabolism of a desert stream. Freshwater Biol. 11(4): 301-307.

Campbell, J. L., J. W. Hornbeck, W. H. Mcdowell, D. C. Buso, J. B. Shanley, and G. E. Likens. 2000. Dissolved organic nitrogen budgets for upland, forested ecosystems in New England. Biogeochem. 49(2): 123-142.

Chescheir, G. M., M. E. Lebo, D. M. Amatya, J. Hughes, J. W. Gilliam, R. W. Skaggs, and R. B. Herman. 2003. Hydrology and water quality of forested lands in eastern North Carolina. Tech. Bull. 320. Raleigh, N.C.: North Carolina State University, North Carolina Agricultural Research Service. 
Cooke, J. G., and A. B. Cooper. 1988. Sources and sinks of nutrients in a New Zealand hill pasture catchment: III. Nitrogen. Hydrol. Proc. 2(2): 135-149.

Cronan, C. S., J. T. Piampiano, and H. H. Patterson. 1999. Influence of land use and hydrology on exports of carbon and nitrogen in a Maine river basin. J. Environ. Qual. 28(3): 953-961.

Cummins, K. W. 1974. Structure and function of stream ecosystems. BioScience 24(11): 631-641.

De Schrijver, A., G. van Hoydonck, L. Nachtergale, L. De Keersmaeker, S. Mussche, and N. Lust. 2000. Comparison of nitrate leaching under silver birch (Betula pendula) and Corsican pine (Pinus nigra spp. Laricio) in Flanders (Belgium). Water, Air, and Soil Pollut. 122(1-2): 77-91.

Diggs, J. 2004. Simulation of hydrology and nitrogen loading of forested fields in eastern North Carolina using DRAINMOD-N-II. MS thesis. Raleigh, N.C.: North Carolina State University.

Dore, J. E., T. Houlihan, D. V. Hebel, G. Tien, L. Tupas, and D. M. Karl. 1996. Freezing as a method of sample preservation for the analysis of dissolved inorganic nutrients in seawater. Marine Chem. 53(3): 173-185.

EEA. 1995. Europe's Environment, the Dobris Assessment. Copenhagen, Denmark: European Environment Agency.

Erisman, J. W., T. Brydges, K. Bull, E. Cowling, P. Grennfelt, L. Nordberg, K. Satake, T. Schneider, S. Smeulders, K. Hoek, J. R. Wisniewski, and J. Wisnniewski. 1998. Nitrogen the Confer- $N$-s: First International Nitrogen Conference. Noordwijkerhout, The Netherlands. Sponsored by The Netherlands' Ministry of Housing, Spatial Planning, and the Environment (VROM) and the National Institute of Public Health and the Environment (RIVM).

Fisher. R. F. 1981. Impact of intensive silviculture on soil and water quality in a coastal lowland. In Tropical Agriculture Hydrology, 299-309. R. Lal and E. W. Russel, eds. New York, N.Y.: Wiley.

Fisher, S. G., and G. E. Likens. 1973. Energy flow in Bear Brook, New Hampshire: An integrative approach to aquatic ecosystem metabolism. Ecol. Monog. 43(4): 421-439.

Fromm, J. H., and R. B. Herrmann. 1996. Jones-5 fertilizer runoff monitoring - 1992. New Bern, N.C.: Weyerhaeuser Research and Development Report, Southern Environmental Field Station.

Gosz, J. R., G. E. Likens, and F. H. Bormann. 1972. Nutrient content of litterfall on the Hubbard Brook experimental forest, New Hampshire. Ecology 53(5): 769-784.

Gunderson, P., and L. Ramussen. 1995. Nitrogen mobility in a nitrogen limited forest at Klosterhede, Denmark, examined by $\mathrm{NH}_{4} \mathrm{NO}_{3}$ addition. Forest Ecol. Mgmt. 71(1-2): 75-88.

Hynes, H. B. N. 1983. Groundwater and stream ecology. Hydrobiologia 100: 93-99.

Johnson, D. W., and D. Todd. 1988. Nitrogen fertilization of young yellow poplar and loblolly pine plantations at differing frequencies. SSSA 52(5): 1468-1477.

Kotlash, A. R., and B. C. Chessman. 1998. Effects of water sample preservation and storage on nitrogen and phosphorus determinations: Implications for the use of automated sampling equipment. Water Res. 32(12): 3731-3737.

Lamersdorf, N. P., K. Blanck, M. Bredemeier, and Y.-J. Xu. 1998. Drought experiments within the solling roof project. Chemosphere 36(4-5): 1161-1166.

Lebo, M. E., and R. B. Herrmann. 1998. Harvest impacts on forest outflow in coastal North Carolina. J. Environ. Qual. 27(6): 1382-1395.

Leonard, J. H. 1977. Nitrogen run-off from radiata pine forest fertilization with urea. New Zealand J. For. Sci. 22(1): 64-80.

Lorenz, K., C. M. Preston, S. Raspe, I. K. Morrison, and K. H. Feger. 2000. Litter decomposition and humus characteristics in Canadian and German spruce ecosystems: Information from tannin analysis and ${ }^{13} \mathrm{C}$ CPMAS NMR. Soil Biol. and Biochem. 32(6): 779-792.
McDonald, M. A., and J. R. Healey. 2000. Nutrient cycling in secondary forests in the Blue Mountains of Jamaica. Forest Ecol. Mgmt. 139: 257-278.

Mee, L. D. 1992. The Black Sea in crisis: A need for concerted international action. Ambio 21(4): 278-286.

Meyer, J. L., G. E. Likens, and J. Sloane. 1981. Phosphorous, nitrogen, and organic carbon flux in a headwater stream. Arch. Hydrobiol. 91(1): 28-44.

Miller, P., A. Bytnerowiez, M. Fenn, M. Poth, P. Temple, S. Schilling, D. Jones, D. Johnson, J. Chow, and J. Watson. 1998. Multidisciplinary study of ozone, acidic deposition, and climate effects on a mixed conifer forest in California, USA. Chemosphere 36(4-5): 1001-1006.

Muzika, R. M., J. B. Gladden, and J. D. Haddock. 1987. Structural and functional aspects of succession in southeastern floodplain forests following a major disturbance. American Midland Naturalist 117(1): 1-9.

Nohrstedt, H. Ö. 1992. Soil water chemistry as affected by liming and $\mathrm{N}$ fertilization at two Swedish coniferous forest sites. Scandinavian J. For. Res. 7(2): 143-153.

North Sea Task Force. 1993. North Sea quality status report. Copenhagen, Denmark: International Council for the Exploration of the Sea.

Oelbermann, M., and A. M. Gordon. 2000. Quality and quantity of autumnal litterfall into a rehabilitated agricultural stream. $J$. Environ. Qual. 29(2): 603-611.

Officer, C. B., R. B. Biggs, J. L. Taft, L. E. Cronin, M. A. Tyler, and W. R. Boynton. 1984. Chesapeake Bay anoxia. Science 223(4631): 22-27.

Owens, M., J. H. N. Garland, I. C. Hart, and G. Wood. 1972. Nutrient budgets in streams. Symp. Zool. Soc. London 29: 21-40.

Perkin Elmer.1988. PE 2400 CHN Elemental Analyzer User's Manual. Norwalk, Conn.: Perkin Elmer Corp.

Peters, N. E., and E. B. Ratcliffe. 1998. Tracing hydrologic pathways using chloride at the Panola Mountain research watershed, Georgia, USA. Water, Air, and Soil Pollut. 105(1-2): 263-275.

Poor, N., R. Pribble, and H. Greening. 2001. Direct wet and dry deposition of ammonia, nitric acid, ammonium, and nitrate to the Tampa Bay estuary, Florida, USA. Atmos. Environ. 35(23): 3947-3955.

Rabalais, N. N, R. E. Turner, and D. Scavia. 2002. Beyond science policy: Gulf of Mexico hypoxia and the Mississippi River. BioScience 52(2): 129-142.

Ring, E., and H. Ö. Nohrstedt. 1993. Stream water chemistry after two forest fertilizations with Skog Vital in central Sweden. Skogforsk Report No. 3. Uppsala, Sweden: Forest Research Institute of Sweden.

Roberson, J. A., J. J. Cassidy, and M. H. Chaudhry. 1988. Hydraulic Engineering. Boston, Mass.: Houghton Mifflin.

Robertson, S. M. C., M. Hornung, and V. H. Kennedy. 2000. Water chemistry of throughfall and soil water under four tree species at Gisburn, northwest England, before and after felling. Forest Ecol. Mgmt. 129: 101-117.

Schroth, G., M. E. A. Elias, K. Uguen, R. Seixas, and W. Zech. 2001. Nutrient fluxes in rainfall, throughfall, and stemflow in tree-based land use systems and spontaneous tree vegetation of central Amazonia. Agric. Ecosys. Environ. 87(1): 37-49.

SCS. 1981. Soil Survey of Washington County, North Carolina. Washington, D.C.: USDA Soil Conservation Service.

Seely, B., K. Lajtha, and G. D. Salvucci. 1998. Transformation and retention of nitrogen in a coastal forest ecosystem. Biogeochem. 42(3): 325-343.

Seitzinger, S. P. 1988. Denitrification in freshwater and coastal marine ecosystems: Ecological and geochemical significance. Limnol. Oceanogr. 33(4): 702-704.

Stay, E. S., A. Katko, K. W. Malueg, M. R. Crouse, S. E. Dominguez, and R. E. Austin. 1979. Effects of forest 
fertilization with urea on major biological components of small Cascade streams, Oregon. EPA-600/3-79-099. Corvallis, Ore.:

U.S. EPA Environmental Research Laboratory.

Triska, F. J., J. R. Sedell, and S. V. Gregory. 1982. Coniferous forest streams. In Analysis of Coniferous Forest Ecosystems in the Western United States, 292-332. R. L. Edmonds, ed. Stroudsburg, Pa.: Hutchinson Ross.

Triska, F. J., J. R. Sedell, K. Cromack Jr., S. V. Gregory, and F. M. McCorison. 1984. Nitrogen budget for a small coniferous forest stream. Ecol. Monog. 54(1): 119-140.
Triska, F. J., V. C. Kennedy, R. J. Avanzino, G. W. Zellweger, and K. E. Bencala. 1989. Retention and transport of nutrients in a third-order stream: Channel process. Ecology 70(6): 1877-1892.

Van Miegroet, H., R. J. Norby, and T. J. Tschaplinski. 1994. Nitrogen fertilization strategies in a short-rotation sycamore plantation. Forest Ecol. Mgmt. 64(1): 13-24.

Wells, C. G., C. E. Murphy, C. Davis, D. M. Stone, and G. J. Hollod. 1985. Effect of sewage sludge from two sources on element flux in soil solution of loblolly pine plantations. In The Forest Alternative for Treatment and Utilization of Municipal and Industrial Wastes, 154-165. D. Cole, C. Henry, and W. Nutter, eds. Seattle, Wash.: University of Washington Press. 
